RESEARCH

SERIES

NUMBER 98

December 2019

\section{THE IMPACTS OF REMOVING FOSSIL FUEL SUBSIDIES AND INCREASING CARBON TAX IN IRELAND}

KELLY DE BRUIN, EOIN MONAGHAN AND AYKUT MERT YAKUT

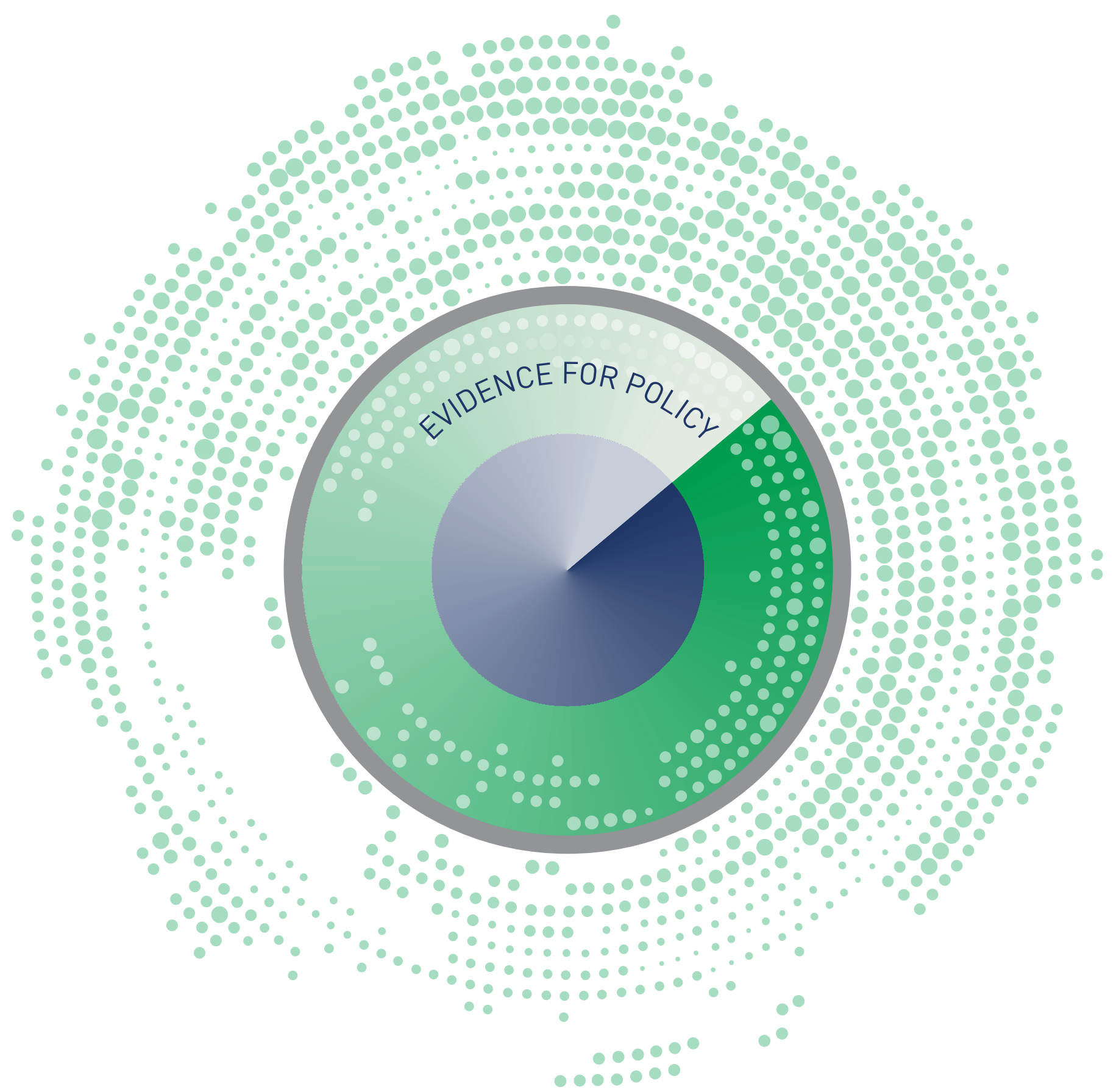




\section{The Impacts of Removing Fossil Fuel Subsidies and Increasing Carbon Tax in Ireland}

Kelly de Bruin

Eoin Monaghan

Aykut Mert Yakut

December 2019

\section{RESEARCH SERIES NUMBER 98}

Available to download from www.esri.ie

(0) The Economic and Social Research Institute

Whitaker Square, Sir John Rogerson's Quay, Dublin 2

ISBN 978-0-7070-0513-3

DOI https://doi.org/10.26504/rs98

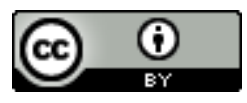

This Open Access work is licensed under a Creative Commons Attribution 4.0 International License (https:// creativecommons.org/licenses/by/4.0/), which permits unrestricted use, distribution, and reproduction in any medium, provided the original work is properly credited. 


\section{ABOUT THE ESRI}

The mission of the Economic and Social Research Institute is to advance evidence-based policymaking that supports economic sustainability and social progress in Ireland. ESRI researchers apply the highest standards of academic excellence to challenges facing policymakers, focusing on 12 areas of critical importance to 21 st century Ireland.

The Institute was founded in 1960 by a group of senior civil servants led by Dr T. K. Whitaker, who identified the need for independent and in-depth research analysis to provide a robust evidence base for policymaking in Ireland.

Since then, the Institute has remained committed to independent research and its work is free of any expressed ideology or political position. The Institute publishes all research reaching the appropriate academic standard, irrespective of its findings or who funds the research.

The quality of its research output is guaranteed by a rigorous peer review process. ESRI researchers are experts in their fields and are committed to producing work that meets the highest academic standards and practices.

The work of the Institute is disseminated widely in books, journal articles and reports. ESRI publications are available to download, free of charge, from its website. Additionally, ESRI staff communicate research findings at regular conferences and seminars.

The ESRI is a company limited by guarantee, answerable to its members and governed by a Council, comprising 14 members who represent a cross-section of ESRI members from academia, civil services, state agencies, businesses and civil society. The Institute receives an annual grant-in-aid from the Department of Public Expenditure and Reform to support the scientific and public interest elements of the Institute's activities; the grant accounted for an average of 30 per cent of the Institute's income over the lifetime of the last Research Strategy. The remaining funding comes from research programmes supported by government departments and agencies, public bodies and competitive research programmes.

Further information is available at www.esri.ie 


\section{THE AUTHORS}

Kelly de Bruin and Aykut Mert Yakut are Research Officers and Eoin Monaghan is a Research Assistant at the Economic and Social Research Institute (ESRI).

\section{ACKNOWLEDGEMENTS}

The research carried out in this report was funded by the Department of Communications, Climate Action and Environment (DCCAE) and is part of an ongoing modelling project.

This report has been accepted for publication by the Institute, which does not itself take institutional policy positions. The report has been peer reviewed prior to publication. The authors are solely responsible for the content and the views expressed. 


\section{EXECUTIVE SUMMARY}

\section{Introduction}

A subsidy is classified as potentially environmentally damaging if it is likely to incentivise behaviour that could be damaging to the environment irrespective of its importance for other policy purposes. Examples of such subsidies include providing fossil fuels (including diesel, kerosene, fuel oil, and peat) at lower prices to certain industries and providing fuel allowances to households to alleviate fuel poverty.

While some publicly-funded supports can have important social and economic purposes, they can have a negative impact on the environment. While the main approach in Ireland to address this has been to use different excise duties, Ireland also introduced a carbon tax in 2010. The carbon tax is one of the primary fiscal policy tools used in several countries to reduce human-induced greenhouse gas (GHG) emissions. For the first time after the equalisation of its level on all fossil fuels in 2014, the Irish government increased the carbon tax from $€ 20$ per tonne of $\mathrm{CO}_{2}$ to $€ 26$ in 2020. It is expected that the total carbon tax revenues will increase by $€ 100$ million in 2020, compared to 2019 .

Notwithstanding this, the total budgetary cost of these fossil fuel subsidies, excluding the agriculturerelated ones, was around $€ 2.44$ billion in 2014 , whereas the government's total carbon tax collection was $€ 390.9$ million. In other words, the monetary value of environmentally damaging subsidies was over six times higher than carbon tax revenues. In 2017, the same ratio was slightly higher, since the total value of subsidies increased by $11.85 \%$, whereas the growth rate of total carbon tax revenues was only $7.7 \%$.

This report analyses the economic and environmental impacts of the removal of eight different fossil fuel subsidies in Ireland by using the Ireland Economy-Energy-Environment (I3E) model. In addition, a separate set of scenarios in which the removal of each subsidy is accompanied by a gradual increase in the level of the carbon tax are run to quantify the combined effects of these policy instruments.

\section{Main Findings}

In this subsection, the results of the simultaneous removal of eight different fossil fuel subsidies in 2020 , the scenario named $A L L$, and its extension with an increase in the carbon tax, the scenario named ALLtax, will be summarised. In the latter scenario, the carbon tax is increased by $€ 6$ annually starting from 2020 and reaches $€ 80$ in 2029 . In all scenario analysis considered in this report, it should be noted that it is assumed that the agricultural non-energy, i.e. methane and nitrous oxide, emissions will not decline and the fossil fuel subsidies for the sector are not removed. Furthermore, it is also assumed that there will be no change in other environmental policies and all policy variables are constant at their 2014 levels.

- Along the path of scenario $A L L$, the total level of economy-wide $\mathrm{CO}_{2}$ emissions will be $20.2 \%$ lower in 2030 than its level along the path of business-as-usual. On the other hand, the reductions in emissions reach $31.3 \%$ in 2030 in the scenario of ALL tax. 
- The scenarios of ALL and ALL tax lead to $11.7 \%$ and $18.4 \%$ reductions in non-ETS emissions, respectively. The level of non-ETS emissions, on the other hand, will be $49.5 \%$ and $38.1 \%$ higher than Ireland's legally-binding non-ETS emissions targets for 2030, respectively.

- There are sectoral fossil fuel subsidies to lower the cost of production or to secure the supply of certain commodities for the air and land transportation, electricity and peat production sectors. The removal of these subsidies affects those respective sectoral outputs negatively, but their impacts on other sectors are negligible.

- There are also commodity related subsidies to lower the retail prices of certain commodities, including auto and marked diesel, kerosene, and fuel oil. The removal of these subsidies affects all sectors in an adverse manner except the accommodation and hotels, and public administration sectors. The removal of subsidies on diesel has the highest impacts across the scenarios considered, and the transportation, electricity production, agriculture, and construction sectors are hit the hardest regarding sectoral real value-added.

- An increase in carbon tax with the removal of subsidies amplifies the magnitudes of the adverse sectoral impacts but does not change the affected sectors.

- In the experiments of $A L L$ and ALLtax, the growth rate of real gross domestic product drops negligibly for the period of 2014-2054. The level of inflation is $1 \%$ higher along the path of ALL_tax, compared to business-as-usual.

- The significant impacts on the poorest household groups' disposable incomes can be restricted if the fuel allowances of households are excluded from the removal process of fossil fuel subsidies. In this case, the policy change has slightly progressive impacts on real disposable income and household welfare.

- The results show that the implementation of other existing measures concerning the cessation of coal and peat from electricity production and increasing the share of renewables in electricity production, electrification of transportation, retrofitting, and the contributions of the agriculture sector are also important in the transition to a low-carbon economy. 


\section{Introduction}

The increased emissions of greenhouse gases (GHGs), including water vapour, carbon dioxide, methane, nitrous oxide and ozone, generate a human-induced (anthropogenic) climate change. Its expected outcomes are, in addition to increases in temperature, more variability in temperature and precipitation, increased occurrences of extreme weather events and a rise in sea levels. The exact repercussions of these climatic changes on economies and societies are ambiguous but are expected to reach a $2 \%$ annual reduction in the global gross domestic product in case of a $2.5^{\circ} \mathrm{C}$ increase in temperature (IPCC, 2014). In accordance with increasing awareness of climate change, the global-scale efforts were initiated by the Kyoto Protocol (ratified in 1997 and became effective in 2005) to reduce the GHG emissions and the Paris Agreement (ratified by 195 states and the European Union (EU) in 2015, though the US has started the formal withdrawal process) to limit the increase in global temperature to $1.5^{\circ} \mathrm{C}$.

After ratifying the Paris Agreement, the EU set its Intended Nationally Determined Contributions (INDCs): at least 40\% reduction in GHG emissions (compared to 1990 levels), at least $32 \%$ share for renewable energy, and at least 32.5\% improvement in energy efficiency. Each member state has legallybinding targets for each of these EU targets for 2020 and 2030. The EU introduced an EU-wide carbon allowance market, namely the Emissions Trading System (ETS), that covers emissions of international aviation, industrial processes, and manufacturing combustion to achieve these targets. The ETS works on a cap-and-trade principle: the unit price of an allowance (one metric tonne of carbon dioxide) is determined via an auctioning process for the fixed amount of total allowances. As the firms covered by the ETS increase their ETS emissions, the demand for allowances boosts and therefore the unit price of allowance increases, as does the cost of production. For those firms not covered by the ETS, some member states impose another environmental tax, namely the carbon tax, on the energy commodities to reduce their emissions not covered by the ETS, i.e. non-ETS emissions. ${ }^{1}$

In compliance with the EU targets, Ireland's legally-binding emissions reduction target for 2030 is a $30 \%$ decline in non-ETS emissions compared to 2005 levels. ${ }^{2}$ In order to disincentivise the non-ETS sectors such as land transportation, residential, and agriculture in fossil fuel consumption, the Irish government introduced the carbon tax on these commodities in 2009. The level of the carbon tax, for the first time after 2014 where the government equalised its level on all fossil fuels, increased from $€ 20$ per tonne of $\mathrm{CO}_{2}$ to $€ 26$ in $2020{ }^{3}$ Such an increase is expected to result in a $€ 100$ million rise in the total carbon tax collection, and around $1.6 \%$ increase in the overall excise revenues of the government.

The carbon tax is at the forefront of the discussions regarding environmental policies for three reasons. Firstly, carbon taxation is the most cost-effective way of reducing emissions (Nordhaus, 1993), despite its

1 A firm is not covered by the ETS either because the sector that the firm operates in is exempted (for instance, the agriculture sector) or its combustion capacity is lower than the threshold. For more information, see EPA (2018).

2 The other targets for 2020 are 16\% of final energy use (all sectors), 10\% of energy use in the transport sector, and $12 \%$ of final heat demand must be sourced from renewables.

3 The tax was imposed on solid fuels in 2013 at the level of $€ 10$. The government has declared its commitment: the carbon tax will reach $€ 80$ in 2030 by following a gradually increasing pattern (Government of Ireland, 2019). 
regressive impacts on household welfare: poorer households are disproportionally negatively affected. ${ }^{4}$ Secondly, as an indirect tax on energy commodities, the carbon tax directly affects the commodity prices, which are the primary driver of behavioural changes. Thirdly, the raised revenue due to the imposition of, or an increase in, a tax is intended to be used in financing environmental policies.

An increase in the level of the carbon tax affects all fossil fuel prices simultaneously since the tax is levied as a unit tax per tonne equivalent of carbon in the content of a commodity. In this case, economic agents are expected to switch their demand from fossil fuels to other energy commodities, mainly electricity. As the power generation sector is phasing out its fossil fuel demand and increasing the share of renewable energy sources, the economy-wide emissions will be lower. In addition, attracting individuals in the usage of public transportation and electrification of transportation (both private and public), and retrofitting of the existing housing stock to increase the energy efficiency are also important components of the climate policies.

Notwithstanding this, governments, including the Irish Government, still run fossil fuel subsidy schemes, which can be damaging to the environment irrespective of their importance for other policy purposes. The aims of these subsidies are based on the recipients. For instance, sectoral production subsidies intend to lower the cost of production which, in turn, lowers domestic prices and increases national firms' profits and competitiveness in international markets. Commodity-related subsidies decrease the retail prices of energy commodities via lowering the excise tax burden. Another viable option is supporting poorer households in lowering their home heating costs. Coady et al. (2019) states that 191 countries have subsidy schemes for fossil fuels and the global monetary value of these subsidies was $6.3 \%$ of global gross domestic product (GDP). The authors also mention that the subsidies keep fossil fuel prices well below their efficient levels determined by supply costs, environmental costs, and revenue considerations. However, some of these subsidies, especially commodity-related ones, increase energy consumption and more importantly, they have unintended repercussions on poor households: as the prices of the energy commodities are lower for all households, richer households who are more inclined to use energy commodities benefit more relative to poorer households.

In the case of Ireland, the total budgetary cost of fossil fuel subsidies, excluding the agriculture-related environmentally damaging subsidies, was around $€ 2.44$ billion in 2014 , whereas the government's total carbon tax collection was $€ 390.9$ million in the same year. In other words, the monetary value of fossil fuel subsidies was 6.26 times higher than the tax collection regarding environmental policies. In 2017, the ratio of fossil fuel subsidies to the total carbon tax revenue was 6.5 .

This report analyses the economic and environmental impacts of the removal of eight different fossil fuel subsidies in Ireland by using the Ireland Economy-Energy-Environment (I3E) model. In the scenario analyses, the removal of sectoral fossil fuel subsidies is translated into increases in the production tax rates of the air transportation, peat, electricity production, and land production sectors, whereas the elimination

4 The distributional impacts of an increase in the carbon tax in Ireland have recently been analysed by Bercholz \& Roantree (2019), Tovar Reaños \& Lynch (2019), and de Bruin et al. (2019). The results imply that, as in other developed countries, an increase in the carbon tax has regressive impacts on household disposable income and welfare in Ireland, in the absence of appropriate policy design. 
of subsidies on the energy commodity is introduced as increases in the sales tax rates of diesel (auto and marked), fuel oil and kerosene. The removal of household energy allowances (the sum of meanstested allowances for electricity, gas, and fuel) is treated as a decline in the total government transfers to households. However, since these allowances are received by the poorest households who are on welfare, the shares of the poorest two households groups in urban and rural areas are reduced.

The results reveal that removing subsidies one-by-one does not generate a significant decrease in the overall economic activity measured by real (in 2014 prices) GDP in 2030. The impacts on real investment expenditure are slightly higher than that of real GDP, whereas there are improvements in the net exportsto- and debt-to-GDP ratios, again at negligible levels. The inflation, household real disposable income and welfare impacts are also minimal. Even if all subsidies are removed simultaneously, real GDP will be only $1.3 \%$ lower in 2030, compared to its business-as-usual $(B a U)$ level, which lowers the long-run (for the period 2014-2054) annual average economic growth rate by only 0.027 percentage points compared to its historical long-run growth rate (3.3\%). The decline in real investment expenditure and thus, the capital accumulation is in line with the impacts on real GDP, but the improvements in the net exports-to- and debt-to-GDP ratios are stronger. Overall inflation increases insignificantly, whereas household disposable income and welfare deteriorate, especially for the poorest two household groups in both urban and rural areas. The exclusion of the household allowances from the removal of all fossil fuel subsidies has limited impacts on the macroeconomic and sectoral impacts, whereas it prevents the poorest households from being strictly worse off. In this case, all households are getting worse off, and the impacts across households are $n$-shaped and slightly progressive in both areas of residence. If the government introduces a more ambitious policy change by accompanying the removal of all subsidies in $\mathbf{2 0 2 0}$ by following a gradually increasing trajectory for the level of the carbon tax, the annual average growth rate declines by 0.04 percentage points relative to its historical level. The inflationary and disposable income effects become larger, compared to no increase in the carbon tax scenario, but impacts are small. As in the previous case, excluding the households' allowances from the removal process saves the poorest households from falling into a worse off situation.

In addition to their negligible impacts on the overall macroeconomic environment, the removal of all subsidies and increasing the carbon tax does not help Ireland to meet its 2030 non-ETS emission targets: compared to the target of a $30 \%$ reduction in emissions in 2030, the level of emissions will be $38.1 \%$ higher than its 2005 level. It should be noted that in these scenario analyses, the other climate policies such as electrification of transportation and increasing energy efficiency as well as the agricultural methane and nitrous oxide emissions are assumed not to change during the model horizon. In that respect, the results should be interpreted cautiously: the removal of fossil fuel subsidies and the taxation of carbon can be just a part of a set of policies to achieve the environmental targets.

The report is structured as follows. Section 2 describes the variety of fossil fuel subsidies in different countries and summarises the fossil fuel subsidies in the Irish economy. Section 3 provides the related literature. Section 4 describes the technical details of the I3E model, and Section 5 describes the experiments which are run in the model. The results are discussed in Section 6. Section 7 concludes. 


\section{Fossil Fuel Subsidies}

This section emphasises the scale of fossil fuel subsidies worldwide. We firstly look at the different types of subsidies available in the wider EU and further afield, before secondly outlining in detail the subsidies in the Irish economy which have been modelled for this report.

There are two different definitions for calculating fossil fuel subsidies in an economy, used by both the OECD and the CSO. First is the "budgetary transfers", which is a direct accounting of funding which is made available to enterprises from (in our case) a national budget. Second is the "tax expenditures", which is a relative measure indicating a preferential treatment of fossil fuels in the fiscal structure, assessed against a benchmark tax level for other activities and sectors within each country (OECD, 2018).

\subsection{Global Context}

There have been reasonable global efforts to phase out damaging fossil fuel subsidies over the last decade or so. In 2009, the G20 emphasised its commitment to "rationalise and phase out over the medium term inefficient fossil fuel subsidies that encourage wasteful consumption". 5 However, the active response has tended not to have matched the vocal support. Indeed, Coady et al. (2019) suggests that estimates of global fossil fuel subsidies in 2017 exceeded US\$5 trillion, an increase from the 2015 level of US\$4.7 trillion. The paper contends that relatively large economic and environmental benefits could have been

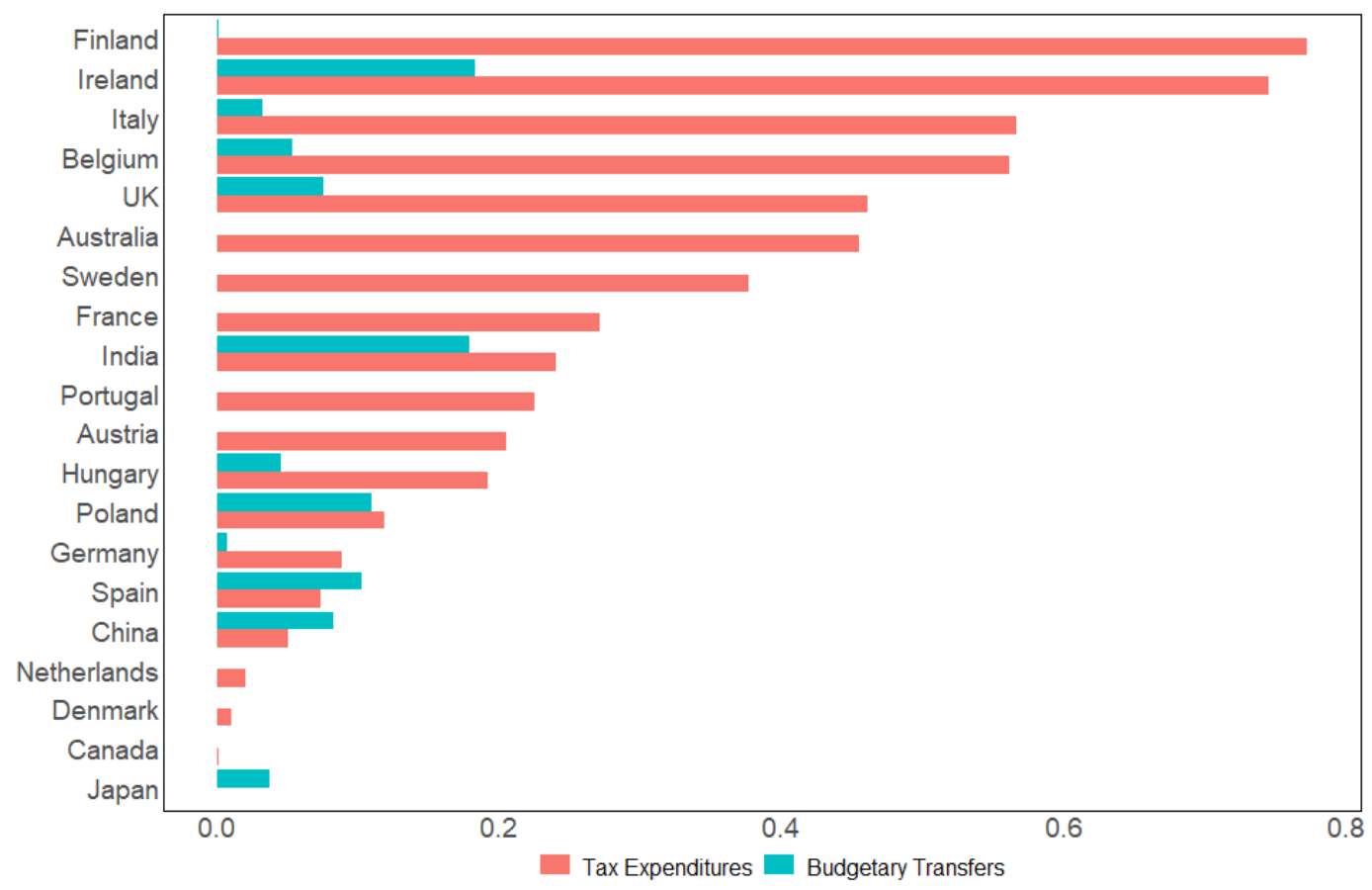

Figure 1: Fossil Fuel Subsidies by Country in 2017, percentage of GDP

Source: Authors' calculations based on OECD and CSO data on fossil fuel subsidies

5 G20 Leaders Statement from the Pittsburgh Summit, September 2009. Accessed here: https://bit. ly/371qWao. 
realised had fuel pricing been set efficiently. For example, in 2015, global carbon emissions could have decreased by $28 \%$, and government revenue could have increased by $3.8 \%$ of GDP.

This section places the extent of Irish fossil fuel subsidies in a global context, by outlining the fossil fuel support schemes in place in various European and non-European countries. It further highlights any steps that have been taken to phase out these environmentally damaging subsidies. To provide a comparison, a summary of the total fossil fuel subsidies to GDP $^{6}$ ratio, in the distinction of budgetary transfers and tax expenditures, for selected countries in 2017 is given in Figure $1 .^{7}$

For the tax expenditures method (which represents the largest method of subsidising fossil fuels), Ireland has the second-highest level of fossil fuel subsidies after Finland, when measured as a percentage of GDP $(0.75 \%$ vs $0.77 \%)$. Ireland is followed by Italy $(0.57 \%)$, Belgium $(0.56 \%)$, the UK $(0.46 \%)$ and Australia $(0.46 \%)$. Note, however, that given the variation in fiscal systems and accounting methods in each country, a direct comparison of this measure should be made with a degree of caution.

\subsubsection{Subsidies in Europe}

We provide a brief overview of the varying systems of fossil fuel subsidies in selected European countries. In many cases, the majority of the supports relate to reductions on fuel prices and excise rates, though other country-specific budgetary schemes are also in operation.

The United Kingdom (UK) has a substantial fiscal support structure for fossil fuel subsidies. Over $€ 1.7$ billion budgetary transfer is attributed to aid for the coal industry to protect from inherited liabilities, intended to avoid placing a significant burden on the industry. Tax-related subsidies are also numerous and cover value-added tax (VAT) relief and excise rate relief and reductions. The largest of these, totalling over $€ 4$ billion, is a reduced VAT rate scheme for natural gas. Fuel oils are exempted from excise duty if those oils are not used as fuel in motors, machinery or heat, while income tax relief related to first-year capital allowances for corporations accumulates to over $€ 1$ billion.

While Germany tends to be a pioneer in climate-change reduction policies, a range of fossil fuel subsidies is still available in the German economy. Over $€ 230$ million was made available in the budget for compensation related to the closure of lignite-fired power plants. Other existing subsidies include, among others, tax breaks for the agriculture and manufacturing sectors, energy tax exemption for aviationrelated fuel consumption and energy tax relief for energy-intensive industries. In France, in addition to excise rate and energy tax exemptions, there are also support structures in place related to overseas VAT exemption and taxi-drivers. These measures are also existent in the Spanish economy, and Spain also maintains financial supports for electricity generation from non-renewable sources, as well as giving aid to coal and oil producers to help the production in those sectors.

Even Sweden, in spite of its credible global track record with regards to environmental protection, still maintains a large fossil fuel support structure, in excess of $€ 1$ billion (converted from Swedish krona).

6 GDP data sourced from the UN database https : //bit.1y/33QEv9H.

7 This data is retrieved from the OECD database on fossil fuel supports, available at https://bit. 1y/36XSF J0. It is provided on a per annum basis. In the case of Ireland, however, more comprehensive CSO data are used. 
The two largest contributors to this total are the tax exemption on biofuels and the reduced energy tax rate for diesel used in motor vehicles. Other significant subsidies include tax exemptions (both energy and $\mathrm{CO}_{2}$ taxes) for aviation, delivery shipping and mining.

Finland has similar GHG emissions statistics (around 60 million tonnes of $\mathrm{CO}_{2}$-eq) and $\mathrm{EU}$ binding targets as those of Ireland, as well as a comparable fossil fuel support structure to Ireland. Support is available for the storage of peat, and there are energy tax reductions for diesel, peat and light fuel oil, and carbon tax reductions are available to heat and power-producing sectors. Moreover, there is a wider tax refund available to energy-intensive industries, for their consumption of oil, electricity, gas, etc.

\subsubsection{Subsidies Outside of Europe}

Fossil fuel subsidies also play a central role in the economies of non-EU countries, again primarily in the form of excise rate reductions. In Australia, large contributors to fossil fuel supports include reduced excise rates on fuel and a Fuel Tax Credits System, totalling over $€ 5$ billion, which is akin to other diesel rebate schemes noted in Europe. For China, over 65 billion Chinese Yuan was allocated to groups most affected by the Petroleum Fuel Prices Reform. Elsewhere, tax rebates and exemptions make up the largest portion of tax supports. Reduced excise rates on aviation fuel and a rebate on imported natural gas, for example, save industries billions of Yuan a year. These excise rate reductions are also common in India, with customs duties reductions on oil, and tax reductions on fuels as "declared goods". Canada's fiscal system is comparatively less favourable to fossil fuels, with $€ 5.5$ million accounted for in the OECD data as available tax breaks. Japan is also less supportive of fossil fuel-consuming schemes with most of its largest subsidies relating to overseas oil exploration.

\subsection{The Case of Ireland}

In this section, we provide a brief description of the different fossil subsidies which have been incorporated into the I3E model. The first set of subsidies refers to those which are directly damaging to the environment, while the second set details those modelled subsidies which are indirectly damaging. For modelling purposes, we only consider the eight most significant fossil fuel subsidies in Ireland. ${ }^{8}$ Nonetheless, the chosen subsidies represent a substantial proportion of all that are in the economy. The CSO calculates that there were around $€ 4.2$ billion worth of environmentally damaging fossil fuel subsidies available in the Irish economy in 2014. Of this, $€ 1.8$ billion were agricultural subsidies, which we do not include in our model as these are not fossil fuel-related. Therefore, of the subsidies included in our model, we cover approximately $96 \%$ of all fossil fuel subsidies in the Irish economy in $2014 .^{9}$

8 The types and monetary costs of the other subsidies are available in CSO (2018).

9 The figures provided refer to 2014 values of fossil fuel subsidies, since these are the values used to calibrate the model. For reference, the total cost of environmentally damaging subsidies in 2017 (the latest available data) was $€ 4.15$ billion, of which $€ 1.4$ billion was agricultural subsidies. 


\subsubsection{Directly Damaging Fossil Fuel Subsidies}

These are supports for fossil fuel usage in general, and their total cost in 2014 was $€ 0.62$ billion. The largest of these, the fuel allowance, is a government subsidy afforded to welfare-dependent households to heat their homes during winter. Similarly, the electricity, gas and heating allowances are part of a Households Benefits Package, available to anyone over the age of 70, and certain households under that age. In these cases, a cash credit of $€ 35$ is applied to the individual's monthly energy bill (DEASP, 2018). In 2014, approximately $€ 175$ million was spent on such allowances.

The Public Service Obligation (PSO) Levy is a flat monthly standing VAT-inclusive charge, aimed at promoting renewable energy, which is applied to electricity users. The proceeds of the levy are subsequently distributed to energy producers to subsidise any shortfall in the price which is charged to consumers and the international market price of energy. In 2014, this amounted to $€ 3.57$ for domestic consumers, and $€ 10.82$ for small commercial consumers respectively (CER, 2013). Around $€ 223$ million was spent on the PSO Levy in 2014, $€ 119$ million of which was used to subsidise peat production, although this scheme will be ceased by the end of $2019 .{ }^{10}$

\subsubsection{Indirectly Damaging Fossil Fuel Subsidies}

Indirectly damaging fossil fuel subsidies refer to those subsidies which encourage increased uptake of environmentally-damaging fossil fuels or which facilitate environmentally-damaging practices. Firstly, general indirectly damaging fossil fuel supports come primarily in the form of revenue which is foregone as a result of the excise rates on certain fuels being lower than a certain benchmark rate (in this case, that of unleaded petrol). The fuels modelled in this paper to which the excise rate applies are auto diesel, marked diesel, fuel oil, and kerosene. Moreover, there are sectoral fuel subsidies for the air transportation and land transportation (hauliers). ${ }^{11}$ The amount of calculated indirect subsidies totals over $€ 1.73$ billion. ${ }^{12}$

\section{Related Literature}

Steps to remove fossil fuel subsidies at a global scale are generally few and far between, with varying degrees of efforts from relevant states. IEA and OECD (2018) analyses the current state of play regarding G20 member states' efforts to phase out inefficient fossil fuel subsidies, as had been committed in 2009. They estimate a decrease of around 18\% in subsidies from 2015 to 2016 but recognise around 40

\footnotetext{
10 Some subsidy schemes with a negligible budgetary cost are excluded from our analysis, including a programme for promoting hydrocarbon exploration (PIP, 2018) and the PSO Air Services Scheme to subsidise two internal flight routes (Lee, 2016). In 2014, the total cost of these allocated subsidies was less then $€ 10$ million.

11 The Diesel Rebate Scheme, which is a support mechanism in which the Revenue Commissioners will repay some of the mineral oil tax which a qualifying road transport operator pays, subject to the diesel being purchased by one's business in the state and being used in qualifying motor vehicles for business purposes (Revenue, 2019).

12 Some schemes, including: Vehicle Registration Tax (VRT) relief for leased cars; general VRT exemptions; and a Disabled Drivers and Disabled Passengers Scheme, related to VRT exemptions for specially-adapted vehicles, are also excluded. These amounted to around $€ 52$ million in 2014 .
} 
economies as being subsidisers of fossil fuels. The report suggests that support in OECD countries has "flattened" since 2014. Individual OECD member states have made some efforts to reduce fossil fuel subsidies, though larger support mechanisms still remain. Belgium and France, for example, started plans to erase the tax differentiation between gasoline and diesel. A similar policy option is also considered in the recent climate action plan (Government of Ireland, 2019). Finland has increased some energy and $\mathrm{CO}_{2}$ taxes, whilst removing the tax exemption on LPG. The case is similar in Sweden, where most energy and $\mathrm{CO}_{2}$ tax exemptions have been eradicated, alongside the uprating of energy taxes on diesel and gasoline. Small measures taken in France include the increase of diesel taxation to align it with petrol taxation. For the UK, steps have been taken to rebalance the levy rates between energies, aiming to reach equality between gas and electricity by 2025 .

Although there are a large number of countries having similar fossil fuel subsidy schemes, the literature on the removal of these subsidies is quite poor. In this regard, this report not only contributes to our understanding of subsidy removal for the case of Ireland but also fills a gap in the general literature. Steenblik \& Coroyannakis (1995) finds that removing producer and consumer subsidies in Western Europe would lead to environmental improvements, as well as improving competition in national electric power industries. Burniaux \& Chateau (2014) refers to competition effects of subsidy removal: the removal of subsidies in non-OECD countries would lead to a carbon leakage in OECD countries, and thus, an increase in emissions towards 2050. Jewell et al. (2018) also supports this competition perspective, contending that the removal of global fossil fuel subsidies would have a surprisingly small impact on energy demand and emissions since consumers would switch from subsidised oil to coal, while countries that do not remove subsidies would increase natural gas and oil consumption. Outside of Europe, both Lin \& Li (2012) and Ouyang \& Lin (2014) analyse the impacts of removing subsidies for China, using general equilibrium modelling. The former finds that subsidy removals would impact welfare, emissions, and competitiveness disproportionately: those countries without subsidy removals would benefit in competitiveness, compared to those countries that implement the phasing out. The results of the latter study reveal that negative macroeconomic impacts of subsidies removal can be largely mitigated if only $10 \%$

of subsidies are removed while increasing subsidies for renewable energies has positive macroeconomic impacts. Finally, Beaton \& Lonton (2010) evaluates the effectiveness of two strategies (an unconditional cash transfer to households and the roll-out of a programme designed to incentivise household switching from kerosene to LPG usage) used in Indonesia to reduce the impacts of fossil fuel subsidy reform. The paper contends that both programmes were adequately implemented and successful in overturning opposition to a fuel subsidy reform and in counteracting adverse economic effects of the reforms, achieved in a wider context of educating the general population on the benefits of such reforms.

\section{The I3E Model}

The I3E model is the first fully dynamic, i.e. intertemporal, Computable Generable Equilibrium (CGE) model for the Irish economy. In the following subsections, the economic agents defined in the model and 
the interactions across these agents are discussed in a non-technical manner. The technical details of the model economy are provided in de Bruin \& Yakut (2019b). The model parameters are calibrated by using an energy social accounting matrix (ESAM). The data sources and the details of the construction process of the ESAM are available in de Bruin \& Yakut (2019a).

1. Households: The household sector of the I3E model consists of ten representative household groups (RHGs). The RHGs with the abbreviation of u1 to u5 are the urban resident households, and u1 (u5) represents the poorest (richest) RHG. Similarly, the RHGs with the abbreviation of r1 to $\mathrm{r} 5$ are the rural resident households, and r1 (r5) represents the poorest (richest) RHG.

- Households choose the optimal level of composite consumption by maximising their utilities subject to their budget constraint. The budget constraints of RHGs equate the disposable income - the sum of wage income, dividend income, welfare transfers and pension income from the government, and net factor income from abroad - to the sum of total consumption expenditures and savings. Private savings are determined as a residual, i.e. what households do not spend is saved.

- Data Source: The RHGs are constructed by using the HBS of 2015-2016. Each household in the survey is uniquely assigned to a RHG, and then the household-level values of income items and consumption expenditures by commodities are aggregated to generate the RHGlevel figures. The model is able to display heterogeneous policy impacts across household types as the RHGs have distinct compositions of disposable income and consumption. The Survey on Income and Living Conditions (SILC) is used to obtain the composition of household wage income by the types of labour (i.e. low-, medium-, and high-skilled), as the HBS does not provide individual-level data.

2. Firms and Production: The production sector comprises 32 representative activities/firms which represent the main producers in the Irish economy regarding total value-added, labour demand, sectoral emissions. Firms are allowed to produce multiple products, i.e. a firm can produce two or more products which are either secondary outputs of the primary production process or entirely different products. Some of the firms produce only one commodity, e.g. public administration, or the shares of secondary products are quite negligible in total production.

- Twenty-seven out of 32 activities determine the level of physical investment by maximising the value of the firm in an intertemporal manner. ${ }^{13}$ A share of combustion-related emissions of the manufacturing sectors and the emissions of energy production sectors are subject to the EU-ETS legislation. The I3E model has an explicit representation of the ETS: each activity takes into account its composition of energy demand, the activity emissions subject to the

\footnotetext{
13 Having an intertemporal investment decision of firms allows the I3E model to explore economic dynamics in a more realistic framework. In the absence of such a feature, the model dynamics would only rely on the consumption smoothing of households, as households seek to achieve a stable level of utility over time.
} 
ETS, and free allowances to reduce its ETS emissions and thus the cost of the ETS. In this respect, each activity pays the same purchaser, i.e. retail, price to buy an energy commodity but the perceived cost of unit demand is a function of the activity's ETS coverage, free allowances, and the EU-ETS price which is an exogenous variable.

- Data Source: The main data source for inter-sectoral linkages is the Supply and Use Tables (SUTs) provided by the Central Statistics Office (CSO). The original SUTs provide information on which industry produces which products, the monetary value of production of each product, the cost of intermediate inputs, the value of gross value-added (payments to the factors of production), production taxes paid to the government, etc. The Labour Force Survey (LFS) is used to disaggregate the sectoral labour demand into types of labour.

3. Commodities: There are 39 commodities in the I3E model: two of them are entirely imported (crude oil and coal), 33 are both domestically produced and imported, and the supply of four commodities is entirely provided by domestic producers. The energy/carbon commodities included in I3E are peat, coal, natural gas, diesel, gasoline, kerosene, LPG, crude oil, fuel oil, other petroleum products, and electricity. The total domestic demand for a commodity is equal to the sum of six items: intermediate input demand, household demand, government demand, investment demand, trade and transportation margin demand, and finally export demand.

- In the supply side, domestic production and import are assumed to be an imperfect substitute of each other, i.e. a final consumer cannot substitute its domestic demand for import in a one-to-one manner. Each component on the demand side comes from the optimal demand by a user: intermediate input demand-cost minimisation problem; household demand-utility maximisation problem, government demand-fixed share of the total government demand, investment demand-fixed fraction of the total investment expenditures, trade and transportation margin demand-fixed fraction of output, and export demand-revenue maximisation problem. For each commodity, an equilibrium condition is defined and associated with the price of the commodity, i.e. the commodity prices are endogenously solved in the model.

- Data Source: The SUTs also provide data on the sources of supply (domestic production and import) and the sources of demand.

4. Labour Types: There are low-, medium-, and high-skilled labour in the I3E model.

- For the fixed supply of each type of labour, the labour market equilibrium conditions solve for the optimal wage rate.

- Data Source: The SILC and LFS are utilised to get the compositions of wage income of households and labour demand of sectors, respectively. In the SILC, individuals with no formal/primary and lower secondary education are low-skilled, individuals with upper secondary, post leaving cert, and third level (non degree) education are medium-skilled, and finally individuals with third level (with a degree or above) education are high-skilled labour. 
5. Enterprises: The model includes an "enterprises" account, where a representative enterprise is assumed to be the owner of all firms. The account collects all gross sectoral profits and receives transfers from the government, which are fixed in nominal terms, and pays corporate tax to the government. The remaining amount is either saved by the enterprise account (fixed fraction of net-of-tax profit receipts) or paid to households as dividend payments.

6. Government: The I3E model has an explicit representation of the government sector. The government collects direct taxes on labour incomes and sectoral profits (corporate tax), indirect taxes on sales of commodities, the carbon tax on energy commodities, the export tax on exported electricity, production tax on production activities, and half of the cost of ETS due to the EU legislation. The carbon tax, which is exogenously determined by the government, is implemented as a fixed price of per-tonne equivalent of carbon and collected on the domestic consumption of energy-commodities. The government allocates its total revenues to the consumption of commodities, welfare transfers and pension payments to households (fixed in real terms - indexed to the average wage), transfers to enterprises (fixed in nominal terms), and interest payments over the outstanding foreign debt stock. The difference between total revenues and expenditures of the government is public saving which drives changes in the foreign debt stock, i.e. as public saving increases (decreases), the government debt stock becomes lower (higher).

7. Rest of the world: All monetary flows between the rest of the world and Ireland are traced within the RoW account. The sources of the foreign exchange supply are exports of commodities and the net factor income of households. The sources of foreign exchange demand are imports of commodities, the interest payments of the government over the outstanding foreign debt stock, and half of the cost of ETS due to the EU legislation. The difference between the totals of foreign exchange supply and demand is covered by foreign savings, i.e. the current account balance. The

foreign market closure rule implies that for the given level of foreign savings, the equilibrium in the rest of the world account is ensured by the exchange rate adjustment.

\section{Experiments}

Along the baseline (business-as-usual, $B a U$ hereafter) scenario of $\mathrm{I} 3 \mathrm{E}$, the realised changes in international prices have been introduced and no further impositions have been put on international energy prices beyond 2019. In other words, all international energy prices are kept constant at their 2018 levels until the end of the model horizon. In addition, declining EU-ETS allowance figures in the third (2013-2020) and fourth phases (2021-2030) of the EU-ETS and the positive trend in the EU-ETS price have also been introduced along the path of $\mathrm{BaU}$ and all other scenarios. Except for these economic developments, all policy variables are assumed to be fixed at their 2014 levels. For instance, the level of carbon tax per tonne equivalent of $\mathrm{CO}_{2}$ is kept constant at $€ 20$ along the path of $\mathrm{BaU}$. Besides the $\mathrm{BaU}$, eleven experiments are designed to understand the implications of the removal of fossil fuel subsidies on the Irish economy, 
as summarised in Table 1. In all these experiments, all other policy variables are assumed be constant at their calibrated vales for the year 2014.

Table 1: Linking Fossil Fuel Subsidies to the I3E Model

\begin{tabular}{|c|c|c|c|c|c|}
\hline Scenario & Removed Subsidy & $\begin{array}{l}\text { Recipient in } \\
\mathrm{I} 3 \mathrm{E}\end{array}$ & $\begin{array}{l}\text { Total Subsidy, } \\
€ m \text { in } 2014\end{array}$ & $\begin{array}{l}\text { I3E Policy } \\
\text { Variable }\end{array}$ & Change, $\%$ \\
\hline $\mathrm{BaU}$ & $\begin{array}{l}\text { Business-as-usual - no } \\
\text { change in policy }\end{array}$ & & & & \\
\hline PT_PEA & $\begin{array}{l}\text { Electricity Generation } \\
\text { from Peat }\end{array}$ & PEA & 119 & $\begin{array}{l}\text { Production } \\
\text { tax rate }\end{array}$ & $2,245.28$ \\
\hline PT_ELC & $\begin{array}{l}\text { Security of Electricity } \\
\text { Supply }\end{array}$ & ELC & 104.7 & $\begin{array}{l}\text { Production } \\
\text { tax rate }\end{array}$ & 50.53 \\
\hline PT_ATS & $\begin{array}{l}\text { Excise Exemption on } \\
\text { Aviation Fuel }\end{array}$ & ATS & 425.9 & $\begin{array}{l}\text { Production } \\
\text { tax rate }\end{array}$ & 212.07 \\
\hline PT_LTS & Diesel Rebate Scheme & LTS & 21.2 & $\begin{array}{l}\text { Production } \\
\text { tax rate }\end{array}$ & 56.17 \\
\hline ST_DIE1 & $\begin{array}{l}\text { Excise Exemption on } \\
\text { Auto Diesel }\end{array}$ & DIE & 309.4 & Sales tax rate & 25.40 \\
\hline ST_DIE2 & $\begin{array}{l}\text { Excise Exemption on } \\
\text { Marked \& Auto Diesel }\end{array}$ & DIE & 793.6 & Sales tax rate & 65.18 \\
\hline ST_FUO & $\begin{array}{l}\text { Excise Exemption on } \\
\text { Fuel oil }\end{array}$ & FUO & 30.9 & Sales tax rate & $3,096.19$ \\
\hline ST_KRS & $\begin{array}{l}\text { Excise Exemption on } \\
\text { Kerosene }\end{array}$ & KRS & 460.1 & Sales tax rate & $38.70^{*}$ \\
\hline EA_HH & Energy Allowance & $\mathrm{HH}$ & 402.2 & $\begin{array}{l}\text { Transfers \& } \\
\text { share par. }\end{array}$ & -1.87 \\
\hline$\overline{\text { ALL }}$ & All of the above & & & & \\
\hline ALL-HH & $\begin{array}{l}\text { All of the above except } \\
\text { EA_HH }\end{array}$ & & & & \\
\hline
\end{tabular}

Note: The lists of activities and commodities are available in Appendix A. The production tax rates are activity-specific, whereas the sales tax rates are commodity-specific in the I3E model. The last column shows the percentage change in the respective tax rate due to the removal of the subsidy.

*: The value of sales tax rate. Since there was no sales tax on the commodity of kerosene in 2014, the percentage change in the sales tax rate after the removal of the subsidy is undefined.

In the experiments of $P T \_x$, the recipient is a production activity, and the removal of the subsidy affects the production tax rate of the activity. The production tax is paid by the activity to the government over the monetary value of total production. In the experiment of PT PEA, for instance, the peat sector receives the subsidy to produce electricity from peat. In the SUTs for Ireland, the net tax (tax minus subsidy) paid to the government by the peat sector was $€ 5.3$ million. ${ }^{14}$ Removing of the entire subsidy ( $€ 119$ million) paid to the sector increases the production tax rate of the sector by 2,245.3\%: the production tax rate will be 23 times higher than its calibrated value for the year of $2014 .^{15}$

14 As the peat sector is not provided in the original SUTs, the mining sector (NACE 5-9) is disaggregated into peat and other mining sectors. See de Bruin \& Yakut (2019a) for details.

15 In all experiments but $P T_{\_} P E A$, the corresponding I3E policy variable is assumed to change in 2020 and stays at its new level until the end of the model horizon. In the PT_PEA scenario, however, the production tax rate of the peat activity gradually increases and reaches its new level in 2026. 
In the experiments of $S T_{-} y$, the recipient is a commodity, and the removal of the subsidy affects the sales tax rate of the commodity. The sales tax is paid by the commodity to the government over the value of total domestic sales. In the experiment of $S T F U O$, for instance, the fuel oil commodity receives the subsidy to lower the domestic price of fuel oil. In the SUTs for Ireland, the net tax (tax minus subsidy) paid to the government by the commodity of fuel oil was $€ 0.99$ million. ${ }^{16}$ Since the commodity of fuel oil is subsidised hugely, the removal of the subsidy makes the sales tax rate on the commodity 31 times higher than its calibrated value for the year of 2014. In 2014, the Irish government was collecting a carbon tax, but there was no additional sales tax from the consumption of kerosene. Therefore, in the ST_KRS scenario, the removal of the subsidy corresponds to a $31 \%$ sales tax rate on kerosene.

In the experiment $E A H H$, households receive means-tested energy allowances from the government. The subsidy figure in Table 1 is the sum of electricity allowance, gas allowance, fuel allowance, and other supplements (heating allowance). As the eligibility rule to be a recipient of those energy allowances is dependent on welfare transfers of the government, it is assumed that the removal of the household subsidies affects the poorest two quintiles in both areas of residences. Therefore, it is assumed that the value of welfare transfer receipt of each of these four RHGs is reduced by $€ 100 \mathrm{~m}$, and their shares parameters are recalibrated; i.e. the shares of these four RHGs in the total government transfers declined, whereas the shares of the remaining RHGs increased. The total value of government transfers to households decreases by $1.87 \%$ for the year of 2014 .

In the $A L L$ scenario, the combined impacts of the removal of all subsidies are evaluated. In this scenario, the subsidies on both marked and auto diesel are assumed to be removed simultaneously, and the sales tax rate of diesel is assumed to increase by $65.2 \%$. The scenario, namely $A L L-H H$, includes the removal of all subsidies but the energy allowances of households which has the highest adverse effects on household welfare as these allowances are received by the welfare-dependent households.

In addition, a set of scenarios in which each policy option is associated with a gradually increasing carbon tax towards 2030 is run. It is assumed that the level of the carbon tax is increasing by $€ 6$ every year starting from 2020. In 2029, the level of tax reaches $€ 80$ and it stays constant at this level until the end of the model horizon, i.e. 2050. For instance, in the experiment of PT_ELC_tax, the production tax rate of the electricity production sector increases by 50.5\% in 2020 and stays at its new level until the end of the model horizon and the level of carbon tax increases by €6 in every year between 2020 and 2029.

\section{Results}

Along the path of $B a U$, the domestic purchaser prices of LPG, fuel oil, diesel, and kerosene decline in 2030, whereas the prices of coal, natural gas, and gasoline increase in 2030, relative to their levels in 2014. As peat and coal are a close substitute of each other, increasing coal price pushes the price of peat up as well. The price patterns of the primary energy commodities, alterations in the composition

16 All energy commodities are disaggregated from broader energy commodities provided in the SUTs. de Bruin \& Yakut (2019a) provides details. 
of input demand of the electricity production, and the peat activity's increasing electricity supply lower the domestic price of electricity in 2030, relative to 2014. Lower energy prices decrease the cost of production and drag down the domestic prices of all non-energy commodities, although the impacts are at negligible levels.

The combined effects of the realisations on the overall macroeconomic aggregates such as real gross domestic product, government indebtedness, trade balance, etc. are minimal. On the other hand, lower energy prices invoke the domestic demand for the energy commodities and thus result in a $7.6 \%$ increase in the economy-wide $\mathrm{CO}_{2}$ emissions in 2018, relative to 2014. Moreover, the emissions grow at rates of 3.7\% and 3.9\% per annum on average along the path of BaU until 2030 and 2040, respectively, if the energy prices are kept constant at their 2018 levels, as assumed in the model, and there is no change in environmental policies. In other words, the growth rate of emissions exceeds the economic growth rate and increases emissions-to-output ratio, i.e. the Irish economy becomes more carbon-intensive. Although its magnitude is negligible, increasing economic activity makes households better off regarding real disposable income. Higher disposable income and lower commodity prices lead to an increase in private consumption demand of households.

In each policy experiment considered in this study, the main impact comes from direct and indirect changes in the purchaser prices of energy and non-energy commodities, respectively. However, the source of price impact differs across experiments regarding the I3E policy variable affected bt the policy change. For instance, in the experiments of $S T_{-} y$, commodity prices increase due to the removal of subsidies, whereas in the experiments of $P T_{-} x$, the cost of production increases as the rate of production tax increases. In the latter group of experiments, the price impact is indirect as the higher cost of production hinders the supply, which, in turn, leads to higher commodity prices. In the former set, however, the price impacts are direct as purchaser price of a commodity is a function of the sales tax rate. In the experiment of $E A H H$, on the other hand, the main impact comes from changes in household disposable income due to the removal of the energy subsidies. In all experiments, higher prices lower demand on commodities, which hinders the increase in prices as the general equilibrium impacts are fully taken into account. In the following subsections, experiments are explained in a comparative manner.

\subsection{Emissions}

Removing the fossil fuel subsidies is one of the options of the Irish government in reaching its legally binding non-ETS emissions targets for 2030. The targets were set to 33 million tonnes of non-ETS emissions, which corresponds to a $30 \%$ reduction compared to its 2005 level. The results of the I3E model show that removing only one of the considered fossil fuel subsidies and keeping the carbon tax at its current level ( $€ 20$ per tonne of $\mathrm{CO}_{2}$ ) generates a 2.9\%, on average, reduction in the economy-wide $\mathrm{CO}_{2}$ emissions in 2030, relative to $\mathrm{BaU}$, Table 2. The largest emissions reduction is obtained in the scenario of SaleTax_DIE2 (8.4\%), which is followed by ST_KRS (6.1\%), ST_DIE1 (3.7\%) and PT_PEA $(3.3 \%)$ in 2030. 
Table 2: The Level of Economy-wide $\mathrm{CO}_{2}$ Emissions by Scenario, million tonne

\begin{tabular}{lrrr|llll} 
Scenario & 2025 & 2030 & 2040 & Scenario & 2025 & 2030 & 2040 \\
\hline BaU & 49.9 & 58.7 & 81.4 & & & & \\
PT_ATS & 48.6 & 57.1 & 78.9 & PT_ATS_tax & 44.1 & 48.9 & 67.2 \\
PT_ELC & 49.4 & 58.2 & 80.6 & PT_ELC_tax & 44.8 & 49.6 & 68.4 \\
PT_LTS & 49.9 & 58.7 & 81.3 & PT_LTS_tax & 45.2 & 50.1 & 69.0 \\
PT_PEA & 49.0 & 56.8 & 78.4 & PT_PEA_tax & 44.5 & 48.5 & 66.5 \\
ST_DIE1 & 48.1 & 56.5 & 78.3 & ST_DIE1_tax & 43.7 & 48.4 & 66.6 \\
ST_DIE2 & 45.8 & 53.8 & 74.4 & ST_DIE2_tax & 41.6 & 46.1 & 63.4 \\
ST_FUO & 49.7 & 58.5 & 81.0 & ST_FUO_tax & 45.0 & 49.9 & 68.7 \\
ST_KRS & 46.9 & 55.2 & 76.4 & ST_KRS_tax & 42.6 & 47.2 & 64.9 \\
EA_HH & 49.8 & 58.6 & 81.2 & EA_HH_tax & 45.1 & 50.0 & 68.9 \\
ALL & 40.7 & 46.9 & 64.3 & ALL_tax & 37.1 & 40.3 & 55.0 \\
ALL-HH & 40.8 & 47.0 & 64.4 & ALL-HH_tax & 37.2 & 40.5 & 55.2 \\
\hline
\end{tabular}

Note: The list of scenarios is available in Table 1.

On the other hand, PT_LTS and EA_HH have the lowest impacts ( $0.1 \%$ and $0.2 \%$, respectively.) If the government removes all fossil fuel subsidies simultaneously by 2020 without increasing the carbon tax, the decline in the economy-wide $\mathrm{CO}_{2}$ emissions reaches $20.2 \%$ in 2030 , compared to $\mathrm{BaU}$. If the removal of a fossil fuel subsidy is accompanied by a gradual increase in the carbon tax, the average decline in the total emissions increases to $17 \%$. In other words, the positive trend of the carbon tax leads to 14.1 percentage points contribution to the decline in the level of emissions. The removal of all subsidies with the increasing pattern of the carbon tax leads to $31.3 \%$ decline in the total emissions. Excluding the household allowances from the removal of all subsidies regardless of the level of the carbon tax has negative but negligible impacts on the emissions reduction process along the path of $A L L-H H$. Figure 2 shows the level of cumulative emissions in the period of 2014-2040 for three scenarios.

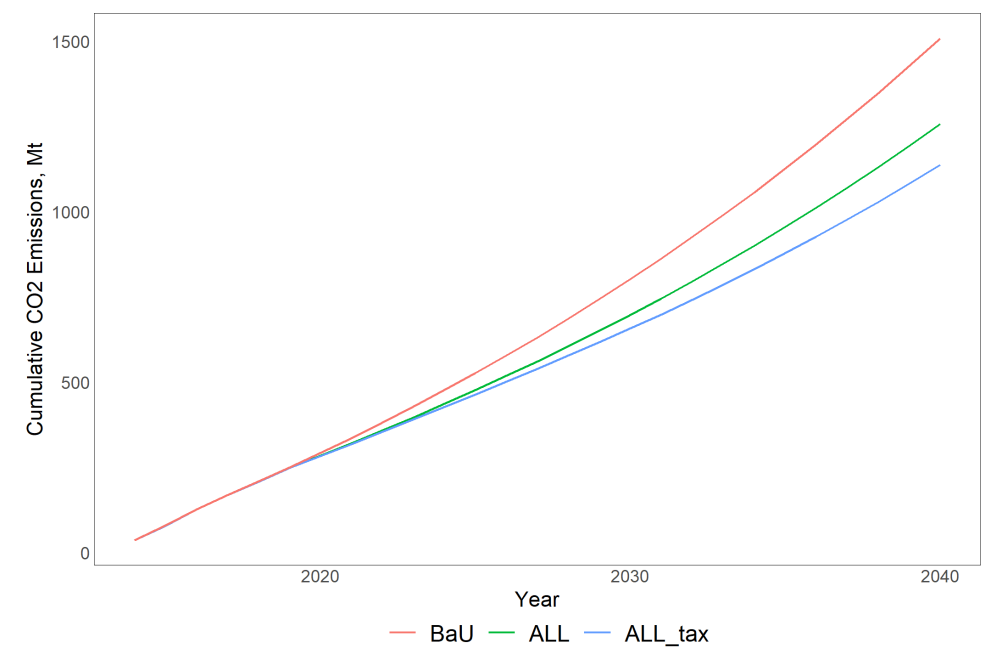

Figure 2: Cumulative Economy-wide $\mathrm{CO}_{2}$ Emissions by Scenario, million tonne 
The level of economy-wide emissions is the sum of the ETS and non-ETS emissions. The former covers the sectoral emissions including combustion-related and process emissions, while the non-ETS emissions, depicted in Figure 3, is the sum of sectoral non-ETS emissions, household emissions, government emissions, and investment-demand related emissions. Figure 3 depicts the path of the total non-ETS emissions, including the Environmental Protection Agency (EPA)'s projections on the agricultural nonenergy emissions. Removing all fossil fuel subsidies would reduce the total non-ETS emissions by $11.7 \%$ in 2030, relative to $B a U$. However, the level of non-ETS emissions will be 49.2 million in 2030 along the path of $A L L$, and it is $49.5 \%$ higher than the Irish emissions target for 2030.

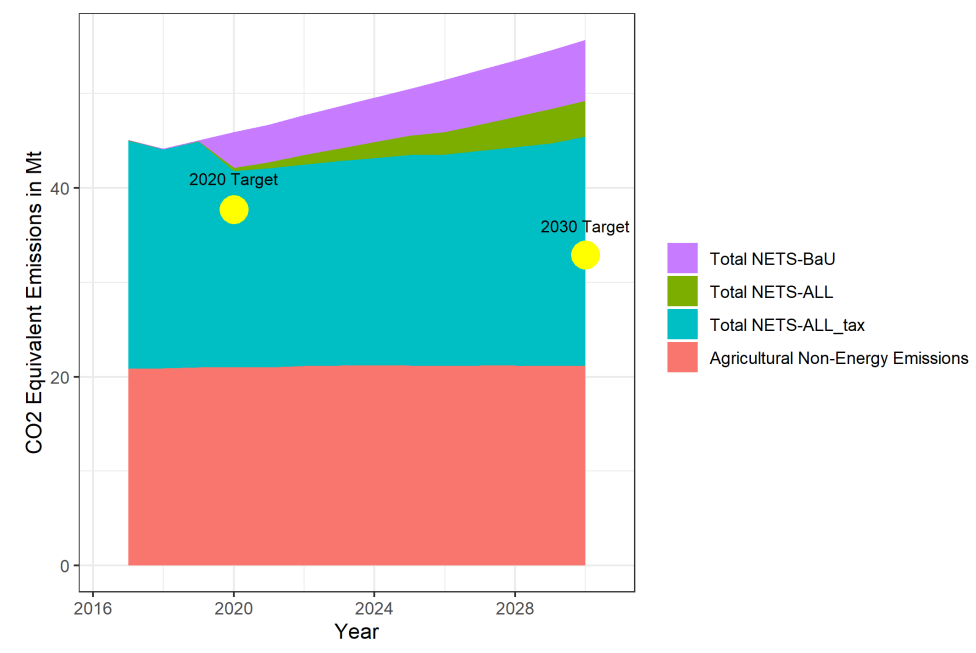

Figure 3: Total Non-ETS $\mathrm{CO}_{2}$ Emissions by Scenario, million tonne

If the removal of the subsidies is complemented by the increasing carbon tax, the reduction reaches $18.4 \%$, compared to $B a U$, but the level of emissions will still be $38.1 \%$ higher than the target for 2030 . In other words, the implementation of other existing measures concerning ceasing of coal and peat from electricity production, increasing the share of renewable in electricity production, electrification of transportation, retrofitting, etc. is also important in the transition to a low-carbon economy.

The removal of diesel subsidies has the highest impacts on the sectoral non-ETS emissions, Table 3, and the transportation, agriculture, construction, and trade sectors are hit the hardest. These results are based on the activities' energy demand compositions in which the share of diesel in the transportation and agriculture sectors' total energy demand is the highest among all energy commodities. ${ }^{17}$

The removal of the fossil fuel subsidies received by the peat activity decreases the sector's total nonETS emissions to one-third of its level along the path of $B a U$. All other scenarios have negligible impacts on the sectoral non-ETS emissions. If the government removes all fossil fuel subsidies at once in 2020, the mining sector's non-ETS emissions decline by more than $70 \%$, and it is followed by the transportation, agriculture, and construction sectors. On the other hand, the gradually increased carbon tax strongly

17 The I3E model, as explained in Section 4, takes into account heterogeneities across the production activities regarding the composition of their energy demand. 
Table 3: Sectoral Non-ETS Emissions in 2030, percentage change w.r.t. $\mathrm{BaU}$

\begin{tabular}{|l|r|r|r|r|r|r|r|r|r|r|}
\hline & AGR & MIN & MAN & CON & TRP & ACC & FSR & TRD & PUB & SER \\
\hline PT_ATS & 0.3 & -0.3 & -0.1 & -0.5 & -1.2 & -0.3 & 0.1 & -0.4 & -0.3 & -0.1 \\
PT_ELC & -0.5 & -1.5 & -0.6 & -0.5 & -0.2 & -0.4 & -0.6 & -0.6 & -0.4 & -0.5 \\
PT_LTS & 0.0 & 0.0 & 0.0 & 0.0 & -0.7 & 0.0 & 0.0 & 0.0 & 0.0 & 0.0 \\
PT_PEA & -0.2 & -68.2 & -0.4 & -0.5 & -0.1 & -0.3 & -0.3 & -0.4 & -0.3 & -0.3 \\
ST_DIE1 & -12.8 & -3.1 & -3.3 & -9.6 & -14.1 & -5.1 & -3.9 & -9.2 & -7.9 & -5.9 \\
ST_DIE2 & -28.1 & -7.0 & -7.4 & -21.2 & -30.6 & -11.5 & -8.7 & -20.5 & -17.6 & -13.1 \\
ST_FUO & -0.3 & -0.3 & -1.6 & -0.2 & -0.2 & -0.1 & -0.2 & -0.4 & -0.4 & -0.3 \\
ST_KRS & 0.0 & -1.7 & -0.8 & -0.6 & -0.7 & -1.3 & -1.0 & -1.1 & -2.9 & -3.0 \\
EA_HH & -0.2 & -0.4 & -0.2 & -0.3 & -0.1 & 0.0 & -0.2 & -0.2 & 0.2 & -0.1 \\
ALL & -28.7 & -71.8 & -10.6 & -22.9 & -32.6 & -13.6 & -10.7 & -22.8 & -21.2 & -17.1 \\
ALL-HH & -28.6 & -71.7 & -10.5 & -22.7 & -32.6 & -13.6 & -10.6 & -22.7 & -21.4 & -17.0 \\
\hline PT_ATS_tax & -22.5 & -23.3 & -17.0 & -20.3 & -27.7 & -18.4 & -13.7 & -20.0 & -18.6 & -16.3 \\
PT_ELC_tax & -23.1 & -24.2 & -17.5 & -20.3 & -27.2 & -18.6 & -14.3 & -20.2 & -18.7 & -16.7 \\
PT_LTS_tax & -22.7 & -23.1 & -17.0 & -19.9 & -27.5 & -18.2 & -13.8 & -19.8 & -18.4 & -16.3 \\
PT_PEA_tax & -22.9 & -74.0 & -17.3 & -20.3 & -27.1 & -18.4 & -14.1 & -20.0 & -18.6 & -16.5 \\
ST_DIE1_tax & -32.7 & -25.3 & -19.6 & -27.4 & -37.3 & -22.3 & -16.9 & -27.1 & -24.7 & -20.9 \\
ST_DIE2_tax & -44.5 & -28.1 & -22.7 & -36.4 & -49.4 & -27.3 & -20.8 & -35.9 & -32.5 & -26.6 \\
ST_FUO_tax & -22.9 & -23.3 & -18.4 & -20.0 & -27.1 & -18.3 & -14.0 & -20.1 & -18.7 & -16.5 \\
ST_KRS_tax & -22.7 & -24.5 & -17.6 & -20.3 & -27.4 & -19.4 & -14.7 & -20.7 & -20.9 & -18.9 \\
EA_HH_tax & -23.0 & -23.5 & -17.2 & -20.2 & -27.2 & -18.3 & -14.1 & -20.0 & -18.3 & -16.4 \\
ALL_tax & -45.0 & -76.8 & -25.5 & -37.8 & -50.8 & -29.2 & -22.6 & -37.8 & -35.6 & -30.1 \\
ALL-HH_tax & -44.8 & -76.7 & -25.3 & -37.6 & -50.7 & -29.1 & -22.4 & -37.6 & -35.7 & -30.0 \\
\hline
\end{tabular}

Note: The acrimonies for sectors are as follows: AGR Agriculture, MIN Mining, MAN Manufacturing, CON Construction, TRP Transportation, ACC Accommodation and Hotels, FSR Financial Services, TRD Trade Activities, PUB Public Administration, and SER Services. The list of aggregated sectors and corresponding sub-sectors is available in Appendix A. Since the entire emissions of the electricity production sector are covered by the ETS, the sector does not have any non-ETS emissions. The transportation (TRP) sector covers the land, air, and water transportation sectors, but its non-ETS emissions exclude the air transportation sector as it does not have any non-ETS emissions.

amplifies the emission reduction in all scenarios by $76 \%$, on average, in the ALL tax scenario, relative to $A L L$. The higher level of the carbon tax more than doubles impacts on the sectoral non-ETS emissions of the manufacturing, accommodation and hotels, and financial services sectors.

The reduction in the sectoral ETS emissions depends on the ETS emissions-to-total-emissions ratio (a fixed parameter), the free allowance-to-ETS-emissions ratio (endogenous variable) of an activity, and the composition of sectoral energy demand (if an activity uses commodities with higher carbon content more, the activity needs an adjustment process to have a reduction in the ETS emissions due to changes in the prices of these commodities). Notice that along the path of each experiment, the decreasing free allowances (until 2030) and the positive trend in the ETS price (until 2018) are taken into account.

As Table 4 indicates, the removal of the diesel-related subsidies generates the strongest impacts, but other activity- or commodity-related subsidies also play important roles in the emissions reduction process. For instance, the removal of the subsidies on aviation fuel (PT_ATS) and kerosene (ST_KRS) hit the air transportation sector hardest as the sector's emissions are entirely covered by the ETS. The removal 
Table 4: Sectoral ETS Emissions, percentage change w.r.t. $\mathrm{BaU}$

\begin{tabular}{|l|rrrr|rrrr|r|}
\hline & \multicolumn{4}{|c|}{ Emissions } & \multicolumn{4}{c|}{ Cost of ETS } & Total Cost \\
\cline { 2 - 8 } & MAN & ELC & \multicolumn{1}{|c|}{ TRP } & SER & MAN & ELC & TRP & SER & \multicolumn{1}{|c}{ of } \\
\hline PT_ATS & -0.7 & -0.6 & -25.0 & -0.1 & -1.0 & -0.6 & -38.4 & -0.1 & -11.7 \\
PT_ELC & -0.4 & -3.2 & -0.1 & -0.5 & -0.6 & -3.2 & -0.2 & -0.5 & -1.5 \\
PT_LTS & -0.1 & 0.0 & -0.1 & 0.0 & -0.1 & 0.0 & -0.1 & 0.0 & -0.1 \\
PT_PEA & -0.3 & -6.8 & -0.1 & -0.4 & -0.4 & -6.8 & -0.1 & -0.4 & -2.8 \\
ST_DIE1 & -2.0 & -1.2 & -3.8 & -7.1 & -2.8 & -1.2 & -5.9 & -7.2 & -3.1 \\
ST_DIE2 & -4.4 & -2.9 & -8.7 & -15.8 & -6.3 & -2.9 & -13.4 & -16.1 & -7.0 \\
ST_FUO & -0.8 & -0.8 & -0.1 & -0.3 & -1.1 & -0.8 & -0.1 & -0.3 & -0.7 \\
ST_KRS & -1.2 & -3.2 & -21.3 & -1.7 & -1.7 & -3.2 & -32.7 & -1.7 & -11.3 \\
EA_HH & -0.2 & -0.3 & -0.1 & -0.1 & -0.3 & -0.3 & -0.1 & -0.1 & -0.2 \\
ALL & -7.6 & -16.3 & -44.6 & -18.5 & -10.8 & -16.3 & -68.4 & -18.8 & -29.6 \\
ALL-HH & -7.4 & -16.1 & -44.5 & -18.4 & -10.5 & -16.1 & -68.3 & -18.7 & -29.5 \\
\hline PT_ATS_tax & -10.7 & -14.9 & -35.5 & -17.5 & -15.2 & -14.9 & -54.5 & -17.9 & -26.4 \\
PT_ELC_tax & -10.5 & -17.2 & -15.1 & -17.9 & -14.9 & -17.2 & -23.2 & -18.2 & -18.2 \\
PT_LTS_tax & -10.2 & -14.5 & -15.0 & -17.5 & -14.5 & -14.5 & -23.1 & -17.8 & -17.0 \\
PT_PEA_tax & -10.3 & -20.1 & -15.0 & -17.7 & -14.7 & -20.1 & -23.1 & -18.1 & -19.3 \\
ST_DIE1_tax & -11.7 & -15.5 & -18.0 & -23.1 & -16.7 & -15.5 & -27.5 & -23.5 & -19.4 \\
ST_DIE2_tax & -13.8 & -16.8 & -21.7 & -29.9 & -19.6 & -16.8 & -33.3 & -30.5 & -22.5 \\
ST_FUO_tax & -10.8 & -15.2 & -15.0 & -17.7 & -15.4 & -15.2 & -23.1 & -18.1 & -17.6 \\
ST_KRS_tax & -11.1 & -17.1 & -32.0 & -18.9 & -15.8 & -17.1 & -49.2 & -19.2 & -26.0 \\
EA_HH_tax & -10.4 & -14.8 & -15.2 & -17.6 & -14.7 & -14.8 & -23.3 & -18.0 & -17.2 \\
ALL_tax & -16.4 & -28.1 & -51.3 & -32.3 & -23.4 & -28.1 & -78.6 & -32.9 & -41.2 \\
ALL-HH_tax & -16.2 & -27.9 & -51.2 & -32.2 & -23.1 & -27.9 & -78.5 & -32.7 & -41.0 \\
\hline
\end{tabular}

Note: The acrimonies for sectors are as follows: MAN Manufacturing, ELC Electricity Production, TRP Transportation, and SER Services. The list of aggregated sectors and corresponding sub-sectors is available in Appendix A, and the list of scenarios is available in Table 1. The ETS emissions of the manufacturing (MAN) sector include the process emissions of the other non-metallic minerals sector. The transportation (TRP) sector's emissions include process emissions resulting from its fuel purchases outside of Ireland. See de Bruin \& Yakut (2019a, 26) and de Bruin \& Yakut $(2019 b, 18)$ for details.

of all subsidies leads to $45 \%$ reduction in aviation emissions. If the government increases the level of carbon tax towards 2030, the ETS emissions of the TRP sector reduce to half, whereas the magnitudes of the decline in the ETS emissions of the ELC and SER sectors are around 30\%. The removal of all subsidies except the household allowances dampens the reductions in sectoral emissions, but the impacts are at negligible levels.

\subsection{Sectoral Impacts}

The removal of a fossil fuel subsidy that is directly related to a sector adversely affects the sector's cost of production via the higher level of production tax and thus leads to a reduction in the sectoral real valueadded, Table 5. In the experiments of $P T_{-} x$, the impacts on the volumes of real value-added of the other sectors that are not directly affected by the removal of subsidy are negligible. Some sectors experience an increase in their real value-added as the production of some sectors shrinks, their labour demand declines 
and employees shift from these sectors to other sectors and lower the cost of production. ${ }^{18}$

Table 5: Sectoral Real Value-added in 2030, percentage change w.r.t. $\mathrm{BaU}$

\begin{tabular}{|c|c|c|c|c|c|c|c|c|c|c|c|}
\hline Scenario & AGR & MIN & MAN & ELC & $\mathrm{CON}$ & TRP & ACC & FSR & TRD & PUB & SER \\
\hline PT_ATS & 0.21 & 0.06 & 0.25 & -0.26 & -0.22 & -9.84 & 0.02 & 0.17 & -0.13 & -0.11 & -0.10 \\
\hline PT_ELC & -0.04 & -0.33 & -0.05 & -2.05 & -0.07 & 0.04 & 0.05 & -0.01 & -0.03 & 0.10 & -0.03 \\
\hline PT_LTS & 0.00 & 0.00 & 0.00 & -0.01 & 0.00 & -0.29 & 0.03 & 0.00 & 0.00 & 0.03 & 0.00 \\
\hline PT_PEA & -0.01 & -9.01 & -0.03 & -0.14 & -0.20 & 0.04 & 0.15 & -0.05 & -0.04 & -0.01 & -0.17 \\
\hline ST_DIE1 & -0.19 & -0.11 & -0.15 & -0.66 & -0.16 & -1.17 & 0.27 & -0.05 & -0.12 & 0.15 & -0.14 \\
\hline ST_DIE2 & -0.43 & -0.25 & -0.33 & -1.56 & -0.36 & -2.82 & 0.64 & -0.10 & -0.28 & 0.29 & -0.32 \\
\hline ST_FUO & -0.04 & -0.04 & -0.05 & 0.00 & -0.01 & -0.03 & 0.03 & 0.01 & -0.01 & 0.03 & 0.00 \\
\hline ST_KRS & 0.08 & -0.35 & -0.02 & -2.28 & -0.17 & -3.30 & 0.19 & -0.01 & -0.21 & 0.22 & -0.04 \\
\hline EA_HH & -0.16 & -0.21 & -0.16 & -0.14 & -0.20 & -0.02 & 0.06 & -0.15 & -0.12 & 0.33 & -0.02 \\
\hline ALL & -0.43 & -9.74 & -0.42 & -6.10 & -1.16 & -14.31 & 1.16 & -0.15 & -0.76 & 0.82 & -0.67 \\
\hline ALL-HH & -0.28 & -9.57 & -0.26 & -5.98 & -0.96 & -14.26 & 1.10 & -0.01 & -0.65 & 0.49 & -0.65 \\
\hline PT_ATS_tax & -0.11 & -1.97 & -0.31 & -2.48 & -0.61 & -13.18 & 0.84 & 0.07 & -0.45 & 0.46 & -0.30 \\
\hline PT_ELC_tax & -0.33 & -2.32 & -0.58 & -4.28 & -0.47 & -4.19 & 0.88 & -0.10 & -0.35 & 0.66 & -0.24 \\
\hline PT_LTS_tax & -0.29 & -2.03 & -0.54 & -2.28 & -0.40 & -4.44 & 0.85 & -0.09 & -0.33 & 0.60 & -0.20 \\
\hline PT_PEA_tax & -0.30 & -10.00 & -0.57 & -2.41 & -0.59 & -4.16 & 0.96 & -0.13 & -0.37 & 0.55 & -0.36 \\
\hline ST_DIE1_tax & -0.45 & -2.11 & -0.66 & -2.89 & -0.54 & -5.19 & 1.08 & -0.12 & -0.43 & 0.66 & -0.33 \\
\hline ST_DIE2_tax & -0.65 & -2.22 & -0.80 & -3.73 & -0.72 & -6.74 & 1.43 & -0.16 & -0.55 & 0.74 & -0.51 \\
\hline ST_FUO_tax & -0.33 & -2.06 & -0.58 & -2.28 & -0.41 & -4.20 & 0.85 & -0.08 & -0.34 & 0.60 & -0.20 \\
\hline ST_KRS_tax & -0.21 & -2.34 & -0.54 & -4.41 & -0.55 & -7.03 & 1.00 & -0.09 & -0.50 & 0.73 & -0.24 \\
\hline EA_HH_tax & -0.45 & -2.23 & -0.69 & -2.42 & -0.61 & -4.27 & 0.89 & -0.24 & -0.44 & 0.91 & -0.22 \\
\hline ALL_tax & -0.66 & -10.67 & -0.88 & -8.08 & -1.47 & -17.22 & 1.93 & -0.21 & -0.99 & 1.19 & -0.84 \\
\hline ALL-HH_tax & -0.51 & -10.50 & -0.73 & -7.94 & -1.27 & -17.20 & 1.87 & -0.06 & -0.87 & 0.86 & -0.82 \\
\hline
\end{tabular}

In the experiment of $P T \_A T S$, the aggregate transportation sector's real value-added shrinks by almost $10 \%$ as the production tax rate of the aviation sector is tripled, relative to $B a U$, and its value-added constitutes more than half of the aggregate value-added of the transportation sector. On the other hand, the removal of the subsidies on the land transportation sector has negligible impacts on the aggregate value-added of the transportation sector along the path of PT_LTS. As the production tax rate of the peat sector dramatically increases between 2020 and 2026, the sectoral real value-added decreases by $9 \%$ along the path of $P T \_P E A$ in 2030, compared to $B a U$.

In the cases of removing the fossil fuel subsidies on commodities, the impacts are the largest for the transportation and electricity production sectors, especially when the subsidies on diesel and kerosene are removed. The removal of households' energy allowances has quite negligible impacts on sectoral value-added. If all fossil fuel subsidies are removed, the transportation, mining and electricity production sectors are hit the hardest. These impacts are mainly driven by the removal of the sector related subsidies, and the higher level of sales tax rates on the diesel and kerosene commodities are also effective.

\footnotetext{
18 It should be noted that since the current version has no involuntary unemployment, the model works under the assumption of full employment: if a sector's labour demand declines, its former employees must be employed by some other sectors.
} 
The sectoral impacts become larger in absolute terms when the subsidy removal process is accompanied by an increase in the level of the carbon tax. For instance, the transportation sector's real value-added decreases by almost three percentage points more in the experiment of ALL tax compared to the ALL scenario. The differences for the electricity production and mining sectors are two and one percentage points, respectively, between these two experiment paths.

If the energy allowances of households are excluded from the removal of all fossil fuel subsidies, the adverse impacts on sectoral real value-added will be lower by seven percentage points, on average, along the paths of $A L L-H H$ and $A L L-H H \_t a x$ relative to $A L L$ and ALL_tax scenarios, respectively. The differences across scenarios are higher than ten percentage points for the sectors of agriculture, mining, manufacturing, electricity production, construction, and financial services.

In all experiments, with or without an increase in the level of the carbon tax, real value-added of the accommodation \& hotels (ACC) and public administration (PUB) sectors are affected positively. The reason for the former sector is that the commodity produced by the sector has the highest share in the composition of private consumption expenditures across service-related sectors. For the latter sector, on the other hand, the primary final consumer of the commodities produced by the PUB sector is the government: $40 \%$ of the total supply of commodity PUB is demanded by the Irish government. ${ }^{19}$

\subsection{Macroeconomic Impacts}

The macroeconomic impacts of the removal of fossil fuel subsidies in 2030 are summarised for selected indicators in Table 6. Removing only one subsidy at the current level of the carbon tax leads to a reduction in the overall economic activity at most by $0.5 \%$ in 2030 along the path of $S T \_D I E 2$ relative to $B a U$, and the annual average growth rate will drop from $3.3 \%$ to $3.292 \% .{ }^{20}$ The experiment is followed by PT_ATS with a $0.34 \%$ reduction in the real GDP and by $S T \_D I E 1$ and $S T_{-} K R S$ with a decline by $0.22 \%$. In line with the overall economic activity, the level of real investment expenditure will be lower than its $B a U$ level. The impact is higher than $1 \%$ in absolute terms only along the path of STDIE2, whereas the average impact across the experiments without an increase in the carbon tax is $0.4 \%$.

In all experiments, the level of nominal GDP decreases since the quantity impact suppresses the price impact. The net exports, i.e. trade balance, slightly ( $0.09 \%$ on average in 2030 , compared to $B a U)$ deteriorate as the higher domestic prices hinder the export demand, i.e. the demand for Irish commodities in international markets. However, as the growth rate of nominal GDP ratio is higher than that of the net exports, in absolute terms, net exports-to-GDP-ratio improves in all scenarios except PTATS , although the impacts are negligible in general. The government foreign debt stock to (nominal) GDP ratio declines in several scenarios. The government consumption demand for commodities is a positive function of the level of nominal GDP: the lower economic activity lowers the expenditures of the government.

\footnotetext{
19 The public commodities are produced by the sector PUB, which covers public administration and defence and compulsory social security (NACE code 84 ), whereas the public policy regarding revenue collection and expenditure execution is carried by the government.

20 The annual average growth rate is calculated for the period of 2014-2054.
} 
Table 6: Macroeconomic Impacts in 2030, percentage change w.r.t. $B a U$

\begin{tabular}{lrrrr}
\hline Scenario & Real GDP & Real Investment & Net Export-to-GDP & Debt-to-GDP \\
\hline PT_ATS & -0.34 & -0.58 & -0.11 & -0.67 \\
PT_ELC & -0.07 & -0.18 & 0.13 & 0.00 \\
PT_LTS & -0.01 & -0.02 & 0.03 & 0.00 \\
PT_PEA & -0.14 & -0.47 & 0.00 & -0.18 \\
ST_DIE1 & -0.22 & -0.52 & 0.14 & -0.23 \\
ST_DIE2 & -0.52 & -1.22 & 0.26 & -0.57 \\
ST_FUO & -0.02 & -0.04 & 0.02 & -0.01 \\
ST_KRS & -0.23 & -0.39 & 0.37 & -0.06 \\
EA_HH & -0.08 & -0.30 & 0.43 & -1.02 \\
ALL & -1.32 & -3.04 & 1.04 & -2.43 \\
ALL-HH & -1.24 & -2.75 & 0.62 & -1.42 \\
\hline PT_ATS_tax & -0.66 & -0.99 & 1.86 & 2.00 \\
PT_ELC_tax & -0.68 & -1.48 & 0.93 & 0.49 \\
PT_LTS_tax & -0.62 & -1.33 & 0.84 & 0.49 \\
PT_PEA_tax & -0.74 & -1.74 & 0.80 & 0.30 \\
ST_DIE1_tax & -0.82 & -1.78 & 0.87 & 0.19 \\
ST_DIE2_tax & -1.09 & -2.41 & 0.88 & -0.24 \\
ST_FUO_tax & -0.63 & -1.35 & 0.83 & 0.49 \\
ST_KRS_tax & -0.82 & -1.65 & 1.07 & 0.34 \\
EA_HH_tax & -0.69 & -1.61 & 1.25 & -0.51 \\
ALL_tax & -1.83 & -4.11 & 1.51 & -2.22 \\
ALL-HH_tax & -1.76 & -3.81 & 1.09 & -1.21 \\
\hline Note The
\end{tabular}

Note: The list of scenarios is available in Table 1.

Moreover, the nominal levels of government transfers to households in the forms of welfare transfers and pension are indexed to the level of mean wage. In line with the economic activity, the average wage and thus the levels of transfers decline. Declining total government expenditure improves public savings and thus allows the government to reduce its debt stock. The largest impact on the debt stock-to-GDP ratio occurs along the path of $E A H H$ where the real value of the government transfers to households is cut by $1.9 \%$. At the current level of the carbon tax, removing all fossil fuel subsidies simultaneously has the highest impact: the level of real GDP will be $1.32 \%$ lower in 2030 relative to $B a U$, and the annual average growth rate will be $3.273 \%$. The decline in the level of real investment reaches $3 \%$, whereas the improvements in the trade balance and debt stock to GDP ratios become more prominent.

If the removal of fossil fuel subsidies is accompanied by an increase in the carbon tax, the real GDP impacts become 0.6 percentage points larger, on average, relative to a no increase in tax scenario. The higher level of the carbon tax amplifies the price impacts of subsidy removals, Table 7, which hinder the demand for commodities and thus the level of real GDP. However, the annual average growth rate of real GDP will be affected marginally: it will drop from $3.3 \%$ to $3.278 \%$ along the path of ST_DIE2_tax and $3.26 \%$ along the path of ALL_tax. In line with the GDP impacts, the real investment expenditure shrinks by around 1 percentage point more, on average, compared to $A L L$. As the higher levels of domestic prices hinder export demand and increase the import demand, the net exports decline by $0.11 \%$, on average in 
2030, compared to $B a U$ ). The decline in nominal GDP suppresses the net export impact, and the net export-to-GDP ratio improves. The decline in nominal GDP lowers the government commodity demand, whereas the accelerated domestic inflation amplifies the government transfer expenditures. As a result, the improvement in the government saving becomes poor and thus the debt-stock-to-GDP-ratio either increases or decreases at a lower rate, compared to a no increase in tax case.

Excluding the household allowances from the removal process of all fossil fuel subsidies, the scenarios of $A L L-H H$ and $A L L-H H_{-}$tax, leads to a lower decline in the level of real GDP by around 13 percentage points, compared to the scenarios of $A L L$ and ALLtax, respectively, and the annual average growth rate of real GDP drops from $3.3 \%$ to $3.276 \%$ and $3.264 \%$. In line with the overall economic performance, the real level of investment expenditures declines less. Moreover, the ratios of net-exports- and debt-stock- to (nominal) GDP improve less, compared to ALL and ALLtax. The reason for the former is that the exclusion of energy allowances of households leads to higher inflation, Table 7, which, in turn, lessens the declines in the domestic commodity prices and thus, restricts the Irish firms' to gain more competitive power in international markets. Besides, as the higher domestic prices also invoke import demand, the improvement in net exports becomes lower, compared to ALL and ALL tax. The debt-to-GDP ratio improves less since the government continues to pay the same amount of welfare transfers in real terms to households, as it does along $B a U$. The higher level of average wage rate, in line with the overall inflation, increases the nominal value of transfers and lowers public savings and thus leads to an increase in the public indebtedness, relative to the scenarios of ALL and ALL_tax.

Table 7: Consumer Price Index in 2030, percentage change w.r.t. $\mathrm{BaU}$

\begin{tabular}{lrrr|lrrr} 
Scenario & Overall & Energy & Non-energy & Scenario & Overall & Energy & Non-energy \\
\hline PT_ATS & 0.21 & -0.18 & 0.27 & PT_ATS_tax & 0.75 & 9.60 & -0.06 \\
PT_ELC & -0.07 & 0.24 & -0.09 & PT_ELC_tax & 0.48 & 10.05 & -0.41 \\
PT_LTS & -0.03 & -0.07 & -0.02 & PT_LTS_tax & 0.51 & 9.72 & -0.36 \\
PT_PEA & 0.11 & 0.83 & 0.05 & PT_PEA_tax & 0.66 & 10.65 & -0.27 \\
ST_DIE1 & 0.17 & 2.18 & -0.02 & ST_DIE1_tax & 0.80 & 12.39 & -0.29 \\
ST_DIE2 & 0.52 & 5.60 & 0.02 & ST_DIE2_tax & 1.26 & 16.43 & -0.17 \\
ST_FUO & -0.01 & 0.06 & -0.02 & ST_FUO_tax & 0.53 & 9.86 & -0.35 \\
ST_KRS & -0.03 & 2.86 & -0.26 & ST_KRS_tax & 0.59 & 13.04 & -0.50 \\
EA_HH & -0.57 & -0.52 & -0.57 & EA_HH_tax & -0.03 & 9.29 & -0.90 \\
ALL & 0.17 & 8.73 & -0.53 & ALL_tax & 0.99 & 19.94 & -0.61 \\
ALL-HH & 0.74 & 9.29 & 0.03 & ALL-HH_tax & 1.55 & 20.50 & -0.05 \\
\hline Note: The list of scenarios is available in Table 1. The Overall CPI covers all commodities, whereas the Energy \\
CPI covers only the energy commodities defined in the I3E model; peat, coal, crude oil, gasoline, diesel, kerosene, \\
fuel oil, liquid petroleum gas (LPG), natural gas, electricity, and other petroleum products. Since the commodities \\
of crude oil and fuel oil are not subject to private consumption, their shares are zero. The Non-energy CPI covers \\
all except energy commodities.
\end{tabular}

The average price changes of the energy commodities, which are measured by the energy consumer price index (CPI), are mainly positive, i.e. the energy inflation is higher relative to $B a U$, and the removal of fossil fuel subsidies on diesel and kerosene has the highest impacts across all scenarios. The reason for the declining energy CPI in the scenario of PTATS is as follows. According to the SUTs, almost 
$60 \%$ of the output of the air transportation sector is exported. When the sectoral subsidy is removed, the cost of production and thus, the price of sectoral output, increases. For the fixed foreign price of the air transportation commodity, the export of the Irish air transportation sector declines more than the decline in the sectoral real value-added. In other words, the sector's supply to the domestic market increases, which, in turn, restricts the increase in its price due to the removal of the subsidy. The changes in the non-energy CPI are negligible. Since the total of the weights of the energy commodities in the overall CPI is around 7\%, the changes in the overall CPI are mainly governed by the changes in the non-energy CPI. In the experiment of $E A \_H H$, all CPIs decrease due to the fact that the removal of household allowances reduces the disposable incomes of the poorest two quintiles in each area of residence and thus lowers their private demand. Since these quintiles are heavily reliant on welfare transfers, a decline in their disposable income dampens their consumption expenditures more than other households. If all fossil fuel subsidies are removed simultaneously, the energy CPI increases by $8.7 \%$ in 2030 compared to $B a U$, whereas the non-energy CPI decreases by $0.5 \%$ and the overall CPI impact is negligible.

In the case of the removal of subsidies with an increase in the level of carbon tax towards 2030, the energy-CPI impacts vary between $9.3 \%$ and $16.4 \%$ across the scenarios considered. The higher level of the sales tax rates of the diesel and kerosene commodities generates the highest increases. In these scenarios, the non-energy CPI declines, compared to $\mathrm{BaU}$ and restricts the change in the overall CPI. In these scenarios, in line with the pattern of the overall economic activity, higher prices lower final demand which, in turn, lessens the pressures on the prices. Along the path of ALLtax, the energy CPI increases by almost $20 \%$, whereas the overall CPI increases by $1 \%$ in 2030, compared to $B a U$. The exclusion of households' energy allowances puts upward pressures on all CPIs: since households' disposable incomes are not as low as in the cases of $A L L$ and ALL_tax scenarios, the private consumption demand does not decline which, in turn, leads to a higher level of inflation.

\subsection{Household Impacts}

The removal of fossil fuel subsidies, except the household allowances, at the current level of the carbon tax ( $€ 20$ per tonne of $\mathrm{CO}_{2}$ ) leads to negligible adverse impacts on the real disposable income of household groups as given in Table 8. The declines in real disposable incomes are in line with the pattern of real GDP: the removal of subsidies on the diesel commodity has the highest impacts and is followed by the removal of subsidies on the air transportation and peat sectors and the commodity of kerosene.

On the other hand, the differences between the scenarios of $A L L$ and $A L L-H H$ and $A L L$ tax and $A L L-H H_{\text {_tax }}$ indicate that the removal of households' energy allowances has the highest impact on real disposable incomes of households. Notice that in the experiment of $E A \_H H$, the real value of government transfers to households is lowered by $1.9 \%$, relative to $B a U$, and the share parameters of the poorest two quintiles are lowered. Since the sum of these share parameters must be 1 , the share parameters of the other households are increased. In line with this, the poorest two household groups in urban and rural areas experience a decline in their disposable incomes, whereas the remaining households' disposable 
Table 8: Household Real Disposable Income in 2030, percentage change w.r.t. $B a U$

\begin{tabular}{|c|c|c|c|c|c|c|c|c|c|c|}
\hline Scenario & $\mathrm{r} 1$ & $\mathrm{r} 2$ & r3 & $\mathrm{r} 4$ & r5 & $\mathrm{u} 1$ & u2 & u3 & $\mathrm{u} 4$ & u5 \\
\hline PT_ATS & -0.15 & -0.21 & -0.24 & -0.25 & -0.23 & -0.15 & -0.16 & -0.19 & -0.23 & -0.24 \\
\hline PT_ELC & -0.04 & -0.04 & -0.04 & -0.04 & -0.05 & -0.04 & -0.03 & -0.03 & -0.04 & -0.06 \\
\hline PT_LTS & 0.00 & 0.00 & 0.00 & 0.00 & 0.00 & 0.00 & 0.00 & 0.00 & 0.00 & -0.01 \\
\hline PT_PEA & -0.10 & -0.11 & -0.11 & -0.10 & -0.12 & -0.10 & -0.08 & -0.09 & -0.11 & -0.15 \\
\hline ST_DIE1 & -0.10 & -0.11 & -0.09 & -0.09 & -0.13 & -0.10 & -0.08 & -0.08 & -0.11 & -0.17 \\
\hline ST_DIE2 & -0.23 & -0.24 & -0.22 & -0.21 & -0.30 & -0.23 & -0.19 & -0.19 & -0.26 & -0.39 \\
\hline ST_FUO & -0.01 & -0.01 & 0.00 & 0.00 & -0.01 & -0.01 & 0.00 & 0.00 & -0.01 & -0.01 \\
\hline ST_KRS & -0.10 & -0.12 & -0.13 & -0.13 & -0.15 & -0.10 & -0.10 & -0.11 & -0.14 & -0.17 \\
\hline EA_HH & -5.09 & -2.15 & 0.45 & 0.29 & 0.13 & -1.10 & -0.20 & 0.57 & 0.30 & 0.04 \\
\hline ALL & -5.68 & -2.83 & -0.22 & -0.38 & -0.67 & -1.68 & -0.73 & 0.00 & -0.44 & -0.93 \\
\hline ALL-HH & -0.59 & -0.68 & -0.68 & -0.68 & -0.80 & -0.58 & -0.53 & -0.58 & -0.74 & -0.97 \\
\hline PT_ATS_tax & -0.39 & -0.46 & -0.46 & -0.47 & -0.55 & -0.39 & -0.36 & -0.40 & -0.51 & -0.65 \\
\hline PT_ELC_tax & -0.29 & -0.31 & -0.28 & -0.28 & -0.39 & -0.29 & -0.24 & -0.25 & -0.34 & -0.50 \\
\hline PT_LTS_tax & -0.25 & -0.27 & -0.24 & -0.24 & -0.34 & -0.25 & -0.21 & -0.22 & -0.30 & -0.44 \\
\hline PT_PEA_tax & -0.34 & -0.37 & -0.34 & -0.34 & -0.45 & -0.34 & -0.29 & -0.30 & -0.40 & -0.57 \\
\hline ST_DIE1_tax & -0.34 & -0.36 & -0.32 & -0.33 & -0.45 & -0.34 & -0.28 & -0.29 & -0.39 & -0.58 \\
\hline ST_DIE2_tax & -0.45 & -0.48 & -0.43 & -0.43 & -0.60 & -0.46 & -0.38 & -0.39 & -0.53 & -0.78 \\
\hline ST_FUO_tax & -0.26 & -0.27 & -0.25 & -0.25 & -0.35 & -0.26 & -0.22 & -0.22 & -0.30 & -0.45 \\
\hline ST_KRS_tax & -0.34 & -0.37 & -0.36 & -0.36 & -0.46 & -0.34 & -0.30 & -0.31 & -0.41 & -0.58 \\
\hline EA_HH_tax & -5.34 & -2.42 & 0.21 & 0.05 & -0.21 & -1.35 & -0.41 & 0.36 & 0.00 & -0.40 \\
\hline ALL_tax & -5.88 & -3.03 & -0.40 & -0.56 & -0.93 & -1.88 & -0.89 & -0.16 & -0.66 & -1.27 \\
\hline ALL-HH_tax & -0.78 & -0.88 & -0.85 & -0.85 & -1.06 & -0.78 & -0.69 & -0.74 & -0.96 & -1.31 \\
\hline
\end{tabular}

incomes increase. The poorest two household groups in rural areas are disproportionately negatively affected compared to the urban-resident poorest two households.

The joint impacts of the removal of subsidies and the increased carbon tax are all negative due to the decline in the overall economic activity. However, the magnitudes of the declines in household real disposable incomes, compared to $B a U$, are not as high as the decline in real GDP since the real values of welfare and pension incomes of households are fixed. In other words, the fixed real values of transfer receipts of households allow them to keep their real income unaffected by downturns in the overall economic activity. In the experiment of EA_HH_tax, the decline in real disposable income becomes 0.3 percentage points higher, in absolute terms, compared to EA_HH. Along the paths of ALL and ALL_tax, the impacts on disposable household incomes are driven by the removal of the household allowances, but all households experience a decline in their disposable incomes. Except for the poorest two household groups in both area of residences, the disposable income effects are progressive: the third household group, namely $r 3$ and $u 3$, are affected less than $r 5$ and $u 5$, respectively.

Along the paths of $A L L-H H$ and $A L L-H H_{-}$tax , all households are getting worse off due to the decline in overall economic activity, and the impacts across households are n-shaped but slightly progressive 
within each area of residence. Notice that in these two experiments, the share parameters of the richest three household groups in the total welfare transfers of the government do not increase, relative to $A L L$ and ALLtax. Therefore, due to the absence of a compensation effect, they are getting more worse off compared to the scenarios of ALL and ALL_tax.

\subsection{Welfare and Income Distribution}

Changes in household welfare are measured by using the concept of equivalent variation (EV). The concept represents the amount by which consumers have to be compensated in monetary terms for the consequences of a policy change, where the prices used in the comparison are the base-run prices (Vellinga, 2011). EV is based on the changes in the value of expenditure function at base-run prices ${ }^{21}$ which, in turn, implies that the changes in EV come from the changes in the volume, i.e. the level of consumption.

Table 9: Equivalent Variation in 2030, percentage change w.r.t. BaU

\begin{tabular}{lrrrrrrrrrr}
\hline Scenario & $\mathrm{r} 1$ & $\mathrm{r} 2$ & $\mathrm{r} 3$ & $\mathrm{r} 4$ & $\mathrm{r} 5$ & $\mathrm{u} 1$ & $\mathrm{u} 2$ & $\mathrm{u} 3$ & $\mathrm{u} 4$ & $\mathrm{u} 5$ \\
\hline PT_ATS & -0.57 & -0.69 & -0.95 & -0.82 & -0.86 & -0.57 & -0.60 & -0.84 & -0.88 & -0.79 \\
PT_ELC & -0.22 & -0.18 & -0.16 & -0.15 & -0.15 & -0.17 & -0.15 & -0.14 & -0.14 & -0.15 \\
PT_LTS & -0.01 & -0.01 & 0.00 & -0.01 & -0.01 & -0.03 & -0.02 & -0.02 & -0.03 & -0.03 \\
PT_PEA & -0.33 & -0.23 & -0.13 & -0.11 & -0.09 & -0.14 & -0.08 & -0.06 & -0.05 & -0.03 \\
ST_DIE1 & -0.59 & -0.73 & -0.73 & -0.81 & -0.80 & -0.31 & -0.35 & -0.38 & -0.42 & -0.49 \\
ST_DIE2 & -1.35 & -1.67 & -1.67 & -1.84 & -1.82 & -0.74 & -0.82 & -0.89 & -0.98 & -1.13 \\
ST_FUO & -0.06 & -0.05 & -0.04 & -0.04 & -0.04 & -0.04 & -0.04 & -0.03 & -0.04 & -0.04 \\
ST_KRS & -1.85 & -1.42 & -1.34 & -1.11 & -1.04 & -0.81 & -0.72 & -0.75 & -0.75 & -0.64 \\
EA_HH & -12.42 & -5.15 & 1.25 & 0.85 & 0.44 & -2.59 & -0.37 & 1.54 & 0.87 & 0.24 \\
ALL & -16.42 & -9.08 & -2.71 & -2.92 & -3.24 & -4.92 & -2.64 & -0.98 & -1.77 & -2.37 \\
ALL-HH & -4.14 & -3.97 & -3.94 & -3.76 & -3.68 & -2.34 & -2.27 & -2.51 & -2.63 & -2.60 \\
\hline PT_ATS_tax & -3.24 & -3.29 & -3.36 & -3.12 & -3.03 & -2.13 & -2.18 & -2.42 & -2.50 & -2.40 \\
PT_ELC_tax & -2.93 & -2.85 & -2.70 & -2.53 & -2.43 & -1.78 & -1.78 & -1.82 & -1.85 & -1.85 \\
PT_LTS_tax & -2.74 & -2.68 & -2.54 & -2.39 & -2.29 & -1.64 & -1.65 & -1.70 & -1.74 & -1.73 \\
PT_PEA_tax & -3.01 & -2.87 & -2.65 & -2.48 & -2.35 & -1.73 & -1.70 & -1.73 & -1.75 & -1.72 \\
ST_DIE1_tax & -3.22 & -3.27 & -3.15 & -3.05 & -2.95 & -1.90 & -1.95 & -2.02 & -2.09 & -2.13 \\
ST_DIE2_tax & -3.84 & -4.02 & -3.92 & -3.89 & -3.81 & -2.28 & -2.36 & -2.47 & -2.59 & -2.71 \\
ST_FUO_tax & -2.78 & -2.72 & -2.58 & -2.43 & -2.32 & -1.66 & -1.67 & -1.72 & -1.75 & -1.74 \\
ST_KRS_tax & -4.32 & -3.89 & -3.68 & -3.34 & -3.15 & -2.33 & -2.27 & -2.34 & -2.37 & -2.25 \\
EA_HH_tax & -15.05 & -7.80 & -1.32 & -1.56 & -1.85 & -4.20 & -2.01 & -0.16 & -0.87 & -1.47 \\
ALL_tax & -18.46 & -11.10 & -4.65 & -4.73 & -4.97 & -6.28 & -4.02 & -2.38 & -3.19 & -3.78 \\
ALL-HH_tax & -6.25 & -6.02 & -5.87 & -5.56 & -5.41 & -3.70 & -3.65 & -3.90 & -4.04 & -4.01 \\
\hline
\end{tabular}

Note: The list of scenarios is available in Table 1. The first five columns of households are rural resident households, and r1 (r5) stands for the poorest (richest) households. The second five columns of households are urban resident households, and u1 (u5) stands for the poorest (richest) households. For more details, see Section 4.

The results given in Table 9 show that in all the experiments, except $E A \_H H$, all households are getting worse off due to lower real consumption which results from both higher commodity prices and lower real disposable income. Along the path of $E A H H$, however, the poorest two household groups

21 Technically, $E V=e\left(p_{\text {base }}, U^{\prime}\right)-e\left(p_{\text {base }}, U_{\text {base }}\right)$ where base stands for the base-run, $U^{\prime}$ is the level of utility along any experiment path, and $e($.$) is the expenditure function.$ 
face a decline in the levels of their welfare due to declines in their disposable incomes. The remaining households gain from the policy change and the impact is progressive: as the level of income increases, the positive impact of the policy change becomes lower. In line with the results in Table 8, the exclusion of the household energy allowances from the removal process of all fossil fuel subsidies leads to lower declines in household welfare, especially for the poorest two household groups in each area of residence as the removal of energy allowances will hit these household groups. On the other hand, the changes in household welfare are regressive in rural areas: the poorer households are disproportionately adversely affected by the removal of all subsidies except the allowances of households. The welfare impacts are n-shaped and progressive in urban areas along the paths of $A L L-H H$ and $A L L-H H \_t a x$.

Table 10: Between-Group Income Distribution in 2030, percentage change w.r.t. $\mathrm{BaU}$

\begin{tabular}{lrrr|lrrr}
\hline Scenarios & Urban & Rural & Urban-to-Rural & Scenarios & Urban & Rural & Urban-to-Rural \\
\hline PT_ATS & -0.09 & -0.08 & 0.02 & PT_ATS_tax & -0.27 & -0.16 & -0.03 \\
PT_ELC & -0.03 & -0.01 & -0.01 & PT_ELC_tax & -0.21 & -0.10 & -0.05 \\
PT_LTS & 0.00 & 0.00 & 0.00 & PT_LTS_tax & -0.19 & -0.09 & -0.04 \\
PT_PEA & -0.06 & -0.02 & -0.01 & PT_PEA_tax & -0.24 & -0.11 & -0.05 \\
ST_DIE1 & -0.07 & -0.03 & -0.02 & ST_DIE1_tax & -0.25 & -0.11 & -0.06 \\
ST_DIE2 & -0.16 & -0.07 & -0.04 & ST_DIE2_tax & -0.33 & -0.15 & -0.08 \\
ST_FUO & -0.01 & 0.00 & 0.00 & ST_FUO_tax & -0.19 & -0.09 & -0.04 \\
ST_KRS & -0.07 & -0.04 & 0.00 & ST_KRS_tax & -0.24 & -0.13 & -0.04 \\
EA_HH & 1.15 & 5.50 & 0.47 & EA_HH_tax & 0.97 & 5.42 & 0.43 \\
ALL & 0.77 & 5.31 & 0.43 & ALL_tax & 0.62 & 5.25 & 0.39 \\
ALL-HH & -0.39 & -0.21 & -0.04 & ALL-HH_tax & -0.54 & -0.28 & -0.08 \\
\hline
\end{tabular}

Note: The list of scenarios is available in Table 1. The term urban (rural) is for the ratio of the richest household's real disposable income to the poorest household's real disposable income in urban (rural) areas. The term urban-to-rural is the ratio of the sum of real disposable incomes of urban resident households to the sum of real disposable incomes of rural resident households.

The I3E model, as with all CGE models, is amenable to quantifying alterations only in betweengroup income distribution due to the fact that the household sector constitutes representative household groups rather than individual households. To this end, three indicators to measure changes in the income distribution are generated. The indicator urban shows the distribution of income between urban resident households, and it is calculated by dividing the richest household's real disposable income to the poorest household. Similarly, the indicator rural is calculated by dividing the rural resident richest household's real disposable income by the rural resident poorest households' disposable income. The last indicator, urban-to-rural, measures the distribution of disposable income across urban and rural areas and it is calculated by dividing the sum of urban resident households' real disposable incomes by the sum of rural resident households' real disposable incomes. Figures in Table 10 are the percentage changes in these indicators relative to $\mathrm{BaU}$. For these indicators, a positive value implies a deterioration, whereas a negative value means an improvement in the between-group income distributions.

The results indicate that the removal of subsidies individually except the household allowances improves all three between-group income distribution indicators within both areas of residences. The impacts on the distribution of income across areas of residence are negligible. If the removal of all subsidies 
is accompanied by an increase in the carbon tax, the magnitudes of improvements become more prominent. On the other hand, the removal of household energy allowances negatively affects the betweengroup income distribution and the impact is much larger in rural areas relative to urban areas as the rural poorest households are more dependent on welfare. Along the path of $E A \_H H$, the income distribution between urban and rural areas changes in favour of urban areas. The removal of all households also leads to increases in all three indicators, but the magnitudes are lower than those of EA_HH as the removal of other subsidies also has negative impacts on the richest households' disposable incomes. However, with the removal of all subsidies with the exclusion of the household allowances, the between-group income distribution changes in favour of the poorest households in both urban and rural areas, and the improvement is greater in rural areas.

\section{Conclusion}

Carbon taxation is the most cost-effective way of reducing emissions, since it induces behavioural changes in economic agents. However, due to its disproportionately negative impacts on poorer households in the absence of appropriate policy design, there is opposition to an increase in the carbon tax, notwithstanding increasing awareness of climate change. In addition to carbon taxation (or environmental taxes in general), governments are implementing several policies regarding shifting power production and transportation from fossil fuel-based technologies to cleaner energies, increasing energy efficiency, etc. On the other hand, several governments, including the Irish government, also conduct various fossil fuel subsidy schemes to support certain sectors, commodities, or households. Ironically, the budgetary cost of these subsidies is much larger than the environmental tax collections in many country cases. This phenomenon implies that governments actually have a wider fiscal space in the alleviation of the adverse climate change impacts by removing these subsidies rather than levying new environmental taxes or increasing the existing environmental tax rates/levels.

This report analyses the economic and environmental impacts of removing eight different subsidy schemes in the case of Ireland, where the budgetary cost of these subsidies is over six times higher than the entire carbon tax revenue of the government. The results indicate that the removal of each of these subsidies has negligible impacts on overall economic activity and household welfare. The exception is in the case of removing household energy allowances, whereby the poorest two household groups in both urban and rural areas are affected negatively in terms of the level of real disposable income and welfare. When the subsidy removal process is combined with an increase in the carbon tax, there are even larger adverse impacts on the economic figures and household welfare.

The emissions results reveal that if all subsidies are removed, the non-ETS $\mathrm{CO}_{2}$ emissions will decline by $11.7 \%$ in 2030 . If the subsidy removal process is accompanied by an increase in the carbon tax, the decline in the non-ETS $\mathrm{CO}_{2}$ emissions will be $18.4 \%$. However, these figures are not sufficient to help the country meet its legally-binding targets for 2030. Under the assumptions that the agricultural non- $\mathrm{CO}_{2}$ emissions will be realised as projected by the EPA and there will be no changes in other policies, the 
non-ETS emissions will be 1.5 times higher than the target. The joint impacts of the removal of subsidies and increasing carbon tax is also not sufficient to meet the target: the level of non-ETS $\mathrm{CO}_{2}$ emissions will be more than one-third higher than the target for 2030. The emissions results clearly show that neither carbon taxation nor removing environmentally damaging fossil fuel subsidies is a viable options by itself to reduce emissions. These policies must be supported by other environmental policies such as electrification of transportation, increasing the share of renewables in power-generation, increasing energy efficiency via retrofitting activities, etc. It should be noted that in order to reduce the possible opposition of the sectors to removing these subsidies, the government may direct this funding to the same sectors to encourage and subsidise their green investment expenditures to reach the low-carbon economy target. The I3E model is in the process of development in order to be able to analyse some of these policy options.

\section{References}

Beaton, C., \& Lonton, L. (2010). Lessons Learned from Indonesia's Attempts to Reform Fossil-Fuel Subsidies (Report). International Institute for Sustainable Development. https://bit.1y/2XcfTqm.

Bercholz, M., \& Roantree, B. (2019). Carbon Taxes and Compensation Schemes (Budget Perspectives 2020 No. 2020/1). The Economic and Social Research Institute. doi: 10.26504/bp202001

Burniaux, J.-M., \& Chateau, J. (2014). Greenhouse Gases Mitigation Potential and Economic Efficiency of Phasing-Out Fossil Fuel Subsidies. International Economics(140), 71-88. doi: 10.1016/j.inteco .2014 .05 .002

Central Statistics Office. (2018). Fossil Fuel and Similar Subsidies 2012-2016 [Research Paper]. https://bit.1y/2Lvm09B.

Coady, D., Parry, I., Le, N.-P., \& Shang, B. (2019). Global Fossil Fuel Subsidies Remain Large: An Update Based on Country-Level Estimates (Working Paper). International Monetary Fund.

Commission for Energy Regulation. (2013). Public Service Obligation Levy 2013/2014. https:// bit.1y/2CE1gTp.

de Bruin, K. C., Monaghan, E., \& Yakut, A. M. (2019). The Economic and Distributional Impacts of an Increased Carbon Tax with Different Revenue Recycling Schemes (ESRI Research Series No. 95). The Economic and Social Research Institute. doi: 10.26504/rs95.pdf

de Bruin, K. C., \& Yakut, A. M. (2019a). Construction of the Energy Social Accounting Matrix for Ireland (ESRI Survey and Statistical Report Series No. 78). Economic and Social Research Institute (ESRI). doi: 10.26504/sustat78 
de Bruin, K. C., \& Yakut, A. M. (2019b). Technical Documentation of I3E Model, Version 2 (ESRI Survey and Statistical Report Series No. 77). Economic and Social Research Institute (ESRI). doi: $10.26504 /$ sustat 77

Department of Employment Affairs and Social Protection. (2018). Household Benefits Package. https://bit.ly/2pdE4bk.

Environmental Protection Agency (EPA). (2018). Who needs a Permit? https://bit. ly/2XaOqoV.

Government of Ireland. (2019). Climate Action Plan 2019 To Tackle Climate Breakdown. https:// bit. 1 y/206Uj2u.

IEA and OECD. (2018). Update on Recent Progress in Reform of Inefficient Fossil Fuel Subsidies that Encourage Wasteful Consumption (Tech. Rep.). International Energy Agency (IEA) and Organisation for Economic Co-operation and Development (OECD). https://bit.1y/2pe6ge9.

IPCC. (2014). Climate Change 2014: Synthesis Report. Contribution of Working Groups I, II and III to the Fifth Assessment Report of the Intergovernmental Panel on Climate Change (R. K. Pachauri \& L. A. Meyer, Eds.). Intergovernmental Panel on Climate Change, Geneva, Switzerland.

Jewell, J., McCollum, D., Emmerling, J., Bertram, C., Gernaat, D. E. H. J., Krey, V., .. Riahi, K. (2018). Limited Emission Reductions from Fuel Subsidy Removal Except in Energy-Exporting Regions. Nature(554), 229-33.

Lee, J. (2016). Public Service Obligation (PSO) Air Services Routes North and South. https:// bit. Iy/2KfRXNm.

Lin, B., \& Li, A. (2012). Impacts of Removing Fossil Fuel Subsidies on China: How Large and How to Mitigate? Energy(44), 741-9. doi: 10.1016/j.energy.2012.05.018

Nordhaus, W. (1993). Reflection on the Economics of Climate Change. Journal of Economic Perspectives, 7(4), 11-25. doi: 10.1257/jep.7.4.11

OECD. (2018). OECD-IEA Fossil Fuel Support and Other Analysis - Methodology. https://bit.1y/ 2OVGBRK.

Ouyang, X., \& Lin, B. (2014). Impacts of Increasing Renewable Energy Subsidies and Phasing Out Fossil Fuel Subsidies in China. Renewable and Sustainable Energy Reviews(37), 933-42. doi: 10.1016/ j.rser.2014.05.013

PIP. (2018). Petroleum Infrastructure Programme. https://bit.1y/2CQ0tx3.

Revenue - Irish Tax and Customs. (2019). Diesel Rebate Scheme. https ://bit. ly/2CIBME4. 
Steenblik, R. P., \& Coroyannakis, P. (1995). Reform of Coal Policies in Western and Central Europe: Implications for the Environment. Energy Policy, 23(6), 537-53. doi: 0301-4215(95)91237-7

Tovar Reaños, M., \& Lynch, M. (2019). Carbon Taxation in Ireland: Distributional Effects of Revenue Recycling Policies (ESRI Special Article). The Economic and Social Research Institute. doi: 10.26504/ QEC2019SUM_SA_Lynch

Vellinga, N. (2011). Trade Liberalization and Taxation: A Multi-sector Dynamic CGE Model for the United Arab Emirates (Working Paper, No. 6). Social \& Economic Research (ISER) Zayed University, Dubai.

\section{Appendix A Lists of Activities and Commodities}

Table A.1: Commodities

\begin{tabular}{|ll|ll|}
\hline AGR & Agriculture & BFM & Basic metal manufacturing \\
PEA & Peat & HTP & High-technology products \\
COA & Coal & TRE & Transportation equipment \\
CRO* & Crude oil & ELC & Electricity \\
OMN* & Other mining products & NGS & Natural gas supply \\
FBT & Food, beverage and tobacco & WAT & Water and sewerage \\
TEX & Textile & CON & Construction \\
WWP & Wood and wood products & TRD & Trade \\
OIN & Other industrial products & LTS & Land transportation \\
GAL & Gasoline & WTS & Water transportation \\
KRS & Kerosene & ATS & Air transportation \\
FUO* & Fuel oil & ACC & Accommodation and hotel services \\
LPG & Liquid petroleum gas & TEL & Telecommunication services \\
DIE & Diesel & FSR & Financial services \\
OPP & Other petroleum products & RES & Real estate services \\
OTM & Other manufacturing & PUB & Public services \\
CHE & Chemicals and chemical products & EDU & Education sector \\
BPP & Basic pharmaceutical products & HHS & Health sector \\
RUP & Rubber and plastic products & SER & Other services \\
ONM & Other non-metallic products & & \\
\hline
\end{tabular}

*: Not subject to private consumption. 
Table A.2: Activities

\begin{tabular}{|c|c|c|c|c|}
\hline \multicolumn{2}{|r|}{ Activity } & NACE Codes & \multicolumn{2}{|c|}{ Aggregate Sector } \\
\hline ACC & Accommodation \& hotel services & $55-56,79$ & $\mathrm{ACC}$ & \\
\hline AGR & Agriculture & $1-3$ & AGR & \\
\hline $\mathrm{CON}$ & Construction & $41-43$ & $\mathrm{CON}$ & \\
\hline ELC & Electricity & & ELC & \\
\hline FSR & Financial services & $64-66,77$ & FSR & \\
\hline PUB & Public sector & 84 & PUB & \\
\hline TRD & Trade & $45-47$ & TRD & \\
\hline BFM & Basic metal manufacturing & $24-25$ & MAN & \\
\hline BPP & Basic pharmaceutical products & 21 & MAN & \\
\hline CHE & Chemicals and chemical products & 20 & MAN & \\
\hline FBT & Food, beverage and tobacco & $10-12$ & MAN & \\
\hline HTP & High-technology products & $26-28$ & MAN & \\
\hline NGS & Natural gas supply & & MAN & \\
\hline OIN & Other industrial products & $17,18,33$ & MAN & \\
\hline ONM & Other non-metallic products & 23 & MAN & Manufacturing \\
\hline OTM & Other manufacturing & $31-32$ & MAN & \\
\hline PET & Petroleum & & MAN & \\
\hline RUP & Rubber and plastic products & 22 & MAN & \\
\hline TEX & Textile & $13-15$ & MAN & \\
\hline TRE & Transportation equipment & $29-30$ & MAN & \\
\hline WAT & Water and sewerage & $36,37-39$ & MAN & \\
\hline WWP & Wood and wood products & 16 & MAN & \\
\hline $\begin{array}{l}\text { OMN } \\
\text { PEA }\end{array}$ & $\begin{array}{l}\text { Other mining products } \\
\text { Peat }\end{array}$ & & $\begin{array}{l}\text { MIN } \\
\text { MIN }\end{array}$ & Mining \\
\hline ATS & Air transportation & 51 & TRP & \\
\hline LTS & Land transportation & 49 & TRP & Transportation \\
\hline WTS & Water transportation & 50 & TRP & \\
\hline EDU & Education sector & 85 & SER & \\
\hline HHS & Health sector & $86-88$ & SER & \\
\hline RES & Real estate services & 68 & SER & Services \\
\hline SER & Other services & remaining* & SER & \\
\hline TEL & Telecommunication services & 61 & SER & \\
\hline
\end{tabular}

*: It excludes NACE codes 5-9 (Mining, Quarrying and Extraction), 19 (Petroleum Products), and 35 (Electricity and Gas Supply).

Note: The activities without NACE codes are further disaggregated sectors. 
Whitaker Square,

Sir John Rogerson's Quay, Dublin 2

Telephone +35318632000

Email admin@esri.ie

Web www.esri.ie

Twitter @ESRIDublin

ISBN 978-0-7070-0513-3 